\title{
Assessment of 4-aminoantipyrine degradation and mineralization by photoelectro-Fenton with a BDD anode: Optimization, treatment in municipal secondary effluent, and toxicity
}

\author{
Lucas de Melo da Silva, ${ }^{[a]}$ Fábio Gozzi, ${ }^{[a]}$ Rodrigo Pereira Cavalcante, ${ }^{[a]}$ Silvio César de Oliveira, ${ }^{[a]}$ Enric \\ Brillas, ${ }^{[b]}$ Ignasi Sirés, ${ }^{*[b]}$ and Amílcar Machulek Junior ${ }^{*[a]}$
}

\begin{abstract}
Aminoantipyrine (4-AA), a persistent metabolite of dipyrone found in natural water, has been treated in $100 \mathrm{~mL}$ of aqueous $0.050 \mathrm{M} \mathrm{Na}_{2} \mathrm{SO}_{4}$ solutions at $\mathrm{pH} 3.0$ by photoelectro-Fenton (PEF) with a 4 W UVA light. The assays were performed in a cell equipped with a BDD anode and an air-diffusion cathode for $\mathrm{H}_{2} \mathrm{O}_{2}$ generation. The formation of an unstable $\mathrm{Fe}(\mathrm{III})-4-\mathrm{AA}$ complex with 1:2 molar ratio was evidenced. A $2^{4}$ central composite design was used to assess the effect of four independent variables on PEF performance. The optimized conditions for $62.5 \mathrm{mg} \mathrm{L}^{-1}$ 4-AA were: current density of $77.5 \mathrm{~mA} \mathrm{~cm}^{-2}$ and $47.75 \mathrm{mg} \mathrm{L}^{-1} \mathrm{Fe}^{2+}$, yielding $99 \%$ 4-AA degradation at $7 \mathrm{~min}$, and $45 \%$ 4-AA mineralization with $3.2 \%$ mineralization current efficiency at $130 \mathrm{~min}$. Slightly slower degradation and similar mineralization were obtained under these conditions when 4-AA was spiked into a municipal secondary effluent, showing a low influence of natural organic matter on PEF. The initially high acute toxicity determined using Artemia salina was largely diminished upon PEF treatment.
\end{abstract}

\section{Introduction}

The inefficient destruction of drugs and their metabolites in municipal wastewater treatments plants (WWTPs) using physicochemical and biological processes is a major cause of accumulation and persistence of such organic pollutants in the aquatic environment. ${ }^{[1-3]}$ Great social alarm has been created by the presence of these compounds, even trace amounts, in water streams due to their potentially harmful effects on the entire ecosystem, particularly on humans and animals. ${ }^{[4,5]}$ Hence, powerful oxidation processes must be developed to ensure their complete removal from wastewater.

Dipyrone (metamizole) is a ubiquitous antipyrine compound, widely prescribed as anti-inflammatory and analgesic drug. Its

[a] Mr. L.M da Silva, Dr. F. Gozzi, Dr. R.P. Cavalcante, Prof. S.C. de Oliveira, Prof. A. Machulek Jr. Institute of Chemistry,

Federal University of Mato Grosso do Sul

Av. Senador Filinto Muller, 1555, CP 549, Campo Grande, MS 79074-460, Brazil

E-mail: machulekjr@gmail.com

[b] Prof. E. Brillas, Prof. I Sirés

Departament de Química Física

Facultat de Química, Universitat de Barcelona

Martí i Franquès 1-11, 08028 Barcelona, Spain

E-mail: i.sires@ub.edu

Supporting information for this article is given via a link at the end of the document. most common primary metabolite is 4-aminoantipyrine (4-AA) which has been detected up to $27 \mu \mathrm{g} \mathrm{L}^{-1}$ in sewage treatment systems. ${ }^{[2,3]}$ 4-AA $\left(\mathrm{C}_{11} \mathrm{H}_{13} \mathrm{~N}_{3} \mathrm{O}, M=203.24 \mathrm{~g} \mathrm{~mol}^{-1}\right)$ is a $\mathrm{N}$ heteroaromatic molecule with a 4-aminopyrazolone group bonded to a benzene ring. The beneficial biological activity of 4-AA has been demonstrated. For example, it allows treating viral disease ${ }^{[6]}$ as well as the formation of stable iron complexes, e.g., with hemoglobin to lower blood flow, ${ }^{[7]}$ although it can produce agranulocytosis, i.e., suppression of the immune system. ${ }^{[8]}$ The removal of 4-AA has been studied by different technologies including ozonation ${ }^{[9]}$ and several advanced oxidation processes (AOPs) such as $\mathrm{UV} / \mathrm{H}_{2} \mathrm{O}_{2},{ }^{[1]}$ photoelectrocatalysis with $\mathrm{TiO}_{2} / \mathrm{ITO}$ anode, ${ }^{[10]}$ and electrochemical oxidation (EO) with boron-doped diamond (BDD) ${ }^{[11]}$ AOPs seem highly promising for treating drugs because they produce strong oxidizing species like hydroxyl radical $\left({ }^{\circ} \mathrm{OH}\right)$ and other reactive oxygen species (ROS), leading to mineralization of most organic pollutants in water. ${ }^{[4,12-14]}$

Photoelectro-Fenton (PEF) is one of the most powerful electrochemical AOPs (EAOPs). It is a sequential or hybrid process in which the oxidation power of ${ }^{\circ} \mathrm{OH}$ generated on site is synergistically combined with the photolytic ability of UVA photons. ${ }^{[15-18]}$ In this method, $\mathrm{H}_{2} \mathrm{O}_{2}$ is continuously produced at a suitable cathode from two-electron reduction of $\mathrm{O}_{2}$ gas via reaction (1). Then, ${ }^{\circ} \mathrm{OH}$ is formed in the bulk upon catalyzed $\mathrm{H}_{2} \mathrm{O}_{2}$ decomposition with added $\mathrm{Fe}^{2+}$ via Fenton's reaction (2): ${ }^{[19-23]}$

$\mathrm{O}_{2(\mathrm{~g})}+2 \mathrm{H}^{+}+2 \mathrm{e}^{-} \rightarrow \mathrm{H}_{2} \mathrm{O}_{2}$

$\mathrm{Fe}^{2+}+\mathrm{H}_{2} \mathrm{O}_{2} \rightarrow \mathrm{Fe}^{3+}+\cdot \mathrm{OH}+\mathrm{OH}^{-}$

Carbonaceous cathodes are known to possess the highest electrocatalytic ability for the promotion of reaction (1), thus yielding an excellent current efficiency. Among these materials, carbon nanotubes, ${ }^{[24,25]}$ carbon sponge, ${ }^{[26]}$ and carbon or graphite felt, ${ }^{[27-30]}$ as well as carbon-PTFE fitted into air-diffusion devices ${ }^{[31-}$ 36], are the most widely employed. On the other hand, heterogeneous ${ }^{\circ} \mathrm{OH}$ can be formed on the anode surface from water discharge at high current. The most powerful anodes are the boron-doped diamond (BDD) thin films due to their large $\mathrm{O}_{2-}$ evolution overpotential and small interaction with heterogeneous $\cdot \mathrm{OH}$, yielding highly reactive $\mathrm{BDD}\left({ }^{\circ} \mathrm{OH}\right)$ as follows: ${ }^{[17,21,34]}$

$\mathrm{BDD}+\mathrm{H}_{2} \mathrm{O} \rightarrow \mathrm{BDD}\left(\bullet^{\circ} \mathrm{OH}\right)+\mathrm{H}^{+}+\mathrm{e}^{-}$ 
Apart from the oxidation with homogeneous and heterogeneous -OH formed from reaction (2) and (3), respectively, in an undivided cell, the UVA radiation in PEF allows the additional destruction of organic matter by different ways: (i) generation of larger $\cdot \mathrm{OH}$ amounts via reaction (4), with $\mathrm{Fe}^{2+}$ regeneration, upon $[\mathrm{Fe}(\mathrm{OH})]^{2+}$ photoreduction, (ii) direct photolysis of photosensitive pollutants, and (iii) photodecomposition of $\mathrm{Fe}$ (III) complexes with some $\mathrm{N}$ derivatives and carboxylic acids according to the general reaction (5) ${ }^{[16,19,21,31-36]}$

$[\mathrm{Fe}(\mathrm{OH})]^{2+}+h v \rightarrow \mathrm{Fe}^{2+}+\cdot \mathrm{OH}$

$[\mathrm{Fe}(\mathrm{OOCR})]^{2+}+h v \rightarrow \mathrm{Fe}^{2+}+\mathrm{CO}_{2}+\mathrm{R}^{\bullet}$

When the solution is not exposed to light, the method is called electro-Fenton (EF), with ${ }^{\circ} \mathrm{OH}$ and $\operatorname{BDD}\left({ }^{\circ} \mathrm{OH}\right)$ acting as the main oxidants. In the absence of $\mathrm{Fe}^{2+}$ catalyst, the treatment is known as electro-oxidation (EO) with electrogenerated $\mathrm{H}_{2} \mathrm{O}_{2}$ (i.e., EO$\mathrm{H}_{2} \mathrm{O}_{2}$ ), being less powerful since homogenous ${ }^{\circ} \mathrm{OH}$ is not produced. ${ }^{[19,21,37,38]}$ Recent advances on the application of EF and PEF processes have demonstrated the superiority of BDD over other anodes (Pt and DSA ${ }^{\circledR}$ ) for the removal of drugs. ${ }^{[23,39-42]}$

This work aims to assess the oxidation power of PEF with a BDD anode and air-diffusion cathode to degrade and mineralize 4-AA. The drug was spiked into pure water or a municipal secondary effluent, always in the presence of $0.050 \mathrm{M} \mathrm{Na}_{2} \mathrm{SO}_{4}$ as supporting electrolyte to ensure high conductivity. First, the possible complexation of the drug with $\mathrm{Fe}^{2+}$ and $\mathrm{Fe}^{3+}$ and its influence on PEF performance was examined. Then, a $2^{4}$ central composite design (CCD) was applied to optimize the current density, initial $\mathrm{Fe}^{2+}$ and 4-AA concentrations, and time using the pure water matrix. Three responses, namely the percentages of 4-AA degradation, 4-AA mineralization, and mineralization current efficiency (MCE) were considered. The best conditions were applied for treating 4-AA spiked into the real water matrix. The time course of the acute toxicity was assessed in the latter matrix by monitoring the mortality of Artemia salina larvae.

\section{Results and Discussion}

\subsection{Complexation of 4-AA with Fe(III)}

Several publications have described the formation of complexes of $\mathrm{Fe}(\mathrm{III})$ with several drugs, including $4-\mathrm{AA} \cdot{ }^{\left[{ }^{[3-46]}\right.}$ To clarify the potential influence of this complex on PEF treatment, a preliminary spectrophotometric study was carried out within the visible range using a solution with $0.246 \mathrm{mM} 4-\mathrm{AA}$ and a much larger content $(0.984 \mathrm{mM})$ of $\mathrm{Fe}^{3+}$, at $\mathrm{pH} 3.0$ under dark conditions Figure 1a highlights the appearance of a wide band between 450 and $650 \mathrm{~nm}$, with $\lambda_{\max }=525 \mathrm{~nm}$, after only $3 \mathrm{~min}$ from mixture preparation, which is due to the formation of a $\mathrm{Fe}(\mathrm{III})-4-\mathrm{AA}$ complex. However, this complex showed a large instability, as confirmed from the drastic absorbance decay at $10 \mathrm{~min}$.
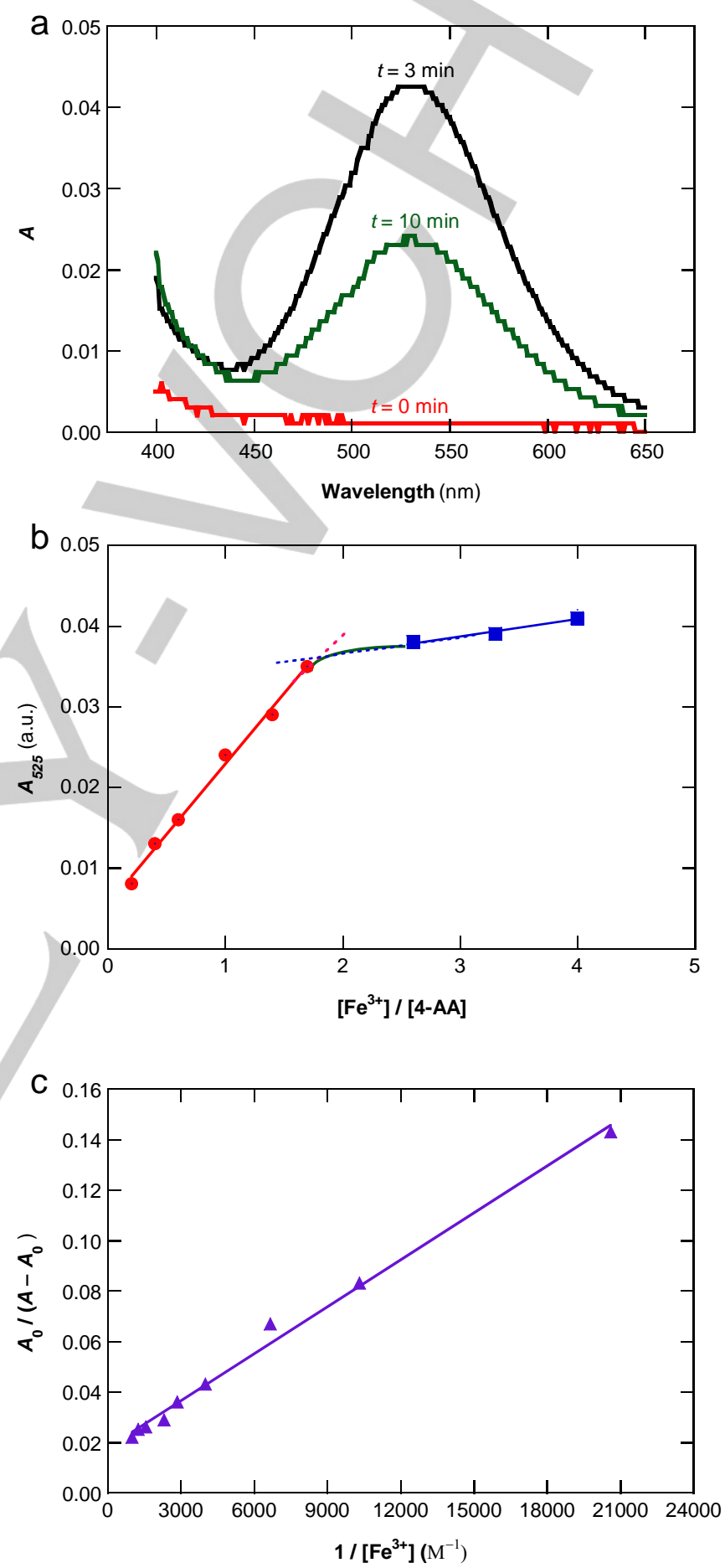

Figure 1. (a) Visible spectra of a solution with $0.246 \mathrm{mM}$ 4-aminoantipyrine (4$\mathrm{AA}$ ) and $0.984 \mathrm{mM} \mathrm{Fe}^{3+}$ in the dark, at different times. (b) Absorbance at $\lambda=$ $525 \mathrm{~nm}$, determined $3 \mathrm{~min}$ after the preparation of fresh solutions containing $0.246 \mathrm{mM} 4-\mathrm{AA}$ and different amounts of $\mathrm{Fe}^{3+}$, vs. $\left[\mathrm{Fe}^{3+}\right] /[4-\mathrm{AA}]$ molar ratio. (c) Variation of $A_{0} /\left(A-A_{0}\right)$ with the reciprocal of $\left[\mathrm{Fe}^{3+}\right]$ for the assays shown in (b). 
When the same experiment was performed under UVA irradiation with a 4-W lamp, the absorption band practically disappeared, thus revealing the photoactivity of the complex (not shown). Conversely, it was confirmed that $\mathrm{Fe}^{2+}$ is unable to form a complex
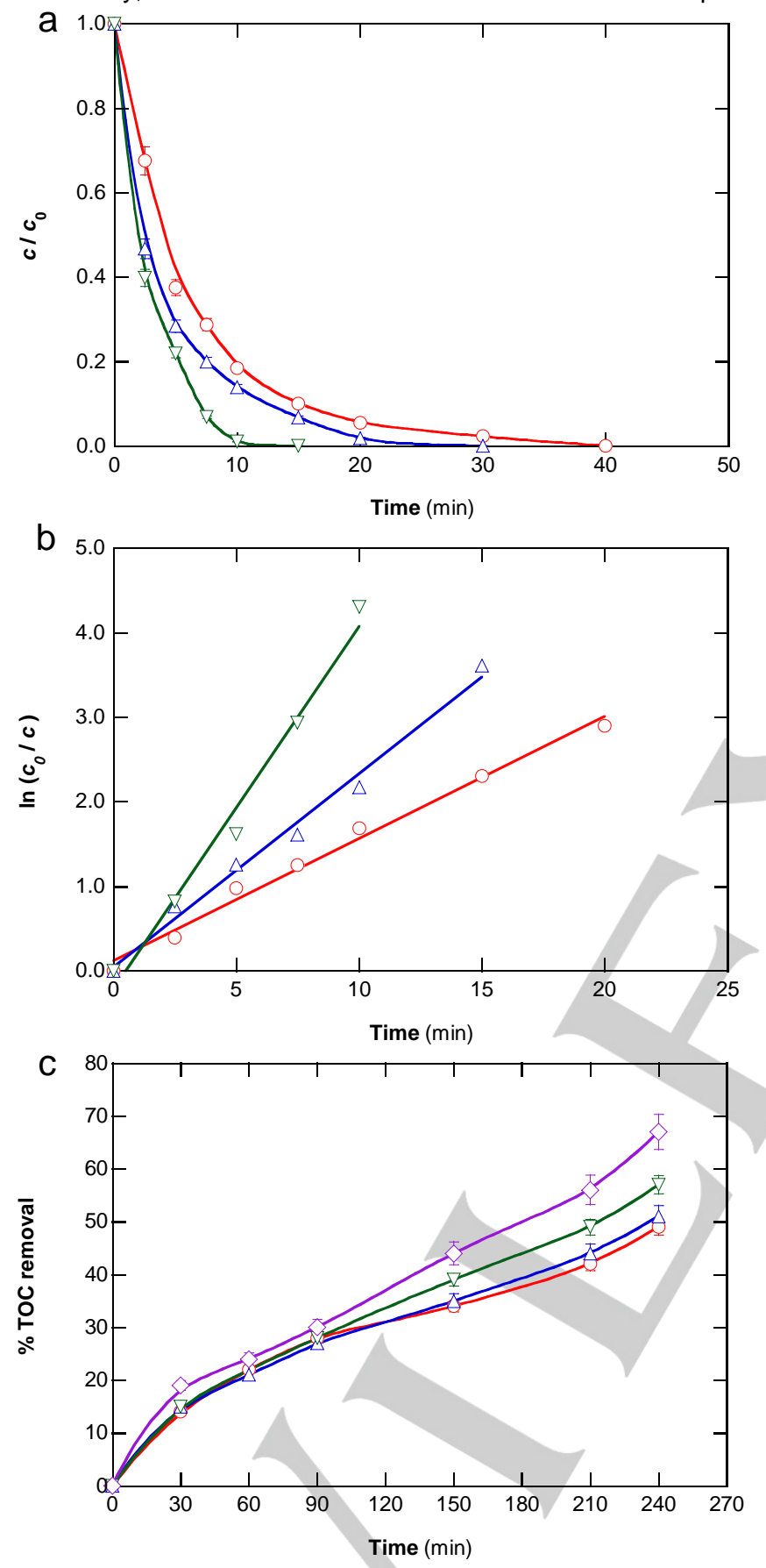

Figure 2. (a) Decay of 4-AA concentration with electrolysis time for the treatment of $100 \mathrm{~mL}$ of a $50 \mathrm{mg} \mathrm{L}^{-1} 4$-AA solution with $0.050 \mathrm{M} \mathrm{Na}_{2} \mathrm{SO}_{4}$ at $\mathrm{pH}$ 3.0 and $25^{\circ} \mathrm{C}$ using a BDD/air-diffusion cell ( $3 \mathrm{~cm}^{2}$ electrode area), at $30 \mathrm{~mA}$ $\mathrm{cm}^{-2}$. Method: (O) Electrochemical oxidation with electrogenerated $\mathrm{H}_{2} \mathrm{O}_{2}$ (EO$\left.\mathrm{H}_{2} \mathrm{O}_{2}\right),\left(\triangle\right.$ ) electro-Fenton (EF) with $15 \mathrm{mg} \mathrm{L}^{-1} \mathrm{Fe}^{2+}$, and $(\nabla)$ photoelectroFenton (PEF) with $15 \mathrm{mg} \mathrm{L}^{-1} \mathrm{Fe}^{2+}$ using a 4-W UVA lamp. (b) Pseudo-first-order kinetic analysis of the above concentration decays. (c) Percentage of TOC removal with electrolysis time for the same trials, along with $(\diamond) \mathrm{PEF}$ with 30 $\mathrm{mg} \mathrm{L}^{-1} \mathrm{Fe}^{2+}$. with the drug, because the visible spectrum of a 4-AA did not change upon $\mathrm{Fe}^{2+}$ addition.

Based on the above findings, a series of absorbance $(A)$ measurements was carried out for solutions containing $0.246 \mathrm{mM}$ 4-AA and $\mathrm{Fe}^{3+}$ concentration ranging from $48.5 \mu \mathrm{M}$ to $0.984 \mathrm{mM}$. The analyses were made at $\lambda_{\max }=525 \mathrm{~nm}$, registering the data 3 min after the preparation of the mixtures, that is, when the maximum absorbance values were obtained. Figure $1 \mathrm{~b}$ evidences the existence of two consecutive linear profiles when $A_{525}$ is plotted against the $\left[\mathrm{Fe}^{3+}\right] /[4-\mathrm{AA}]$ molar ratio. The $A$ value rose rapidly upon $\left[\mathrm{Fe}^{3+}\right] /[4-\mathrm{AA}]$ increase up to ca. 2 , due to the gradually greater chelation of the metal ions with the drug. At $\left[\mathrm{Fe}^{3+}\right] /[4-\mathrm{AA}]$ values greater than 2 , the increase of $A$ became much slower because almost all drug molecules formed a complex with iron ions. This means that the stoichiometry of the $\mathrm{Fe}(\mathrm{III})-4-\mathrm{AA}$ complex was 1:2. The complexation constant $(K)$ was then determined from the following equation: ${ }^{[45]}$

$\frac{A_{0}}{A-A_{0}}=\frac{\varepsilon_{0}}{\varepsilon-\varepsilon_{0}}+\frac{\varepsilon_{0}}{\varepsilon-\varepsilon_{0}} \frac{1}{K\left[\mathrm{Fe}^{3+}\right]}$

where $A_{0}$ and $A$ denote the absorbance in the absence and presence of $\mathrm{Fe}(\mathrm{III})$, respectively, and $\varepsilon_{0}$ and $\varepsilon$ are the molar absorption coefficients of the corresponding solutions. From the good linear correlation between $A_{0} /\left(A-A_{0}\right)$ and $1 /\left[\mathrm{Fe}^{3+}\right]$ depicted in Figure $1 \mathrm{c}\left(R^{2}=0.993\right)$ taking all the data shown in Figure $1 \mathrm{~b}, K$ $=6.2 \times 10^{6} \mathrm{M}^{-1}$ was determined, a value very close to $7.1 \times 10^{6} \mathrm{M}^{-1}$ found in earlier work by potentiometric titration. ${ }^{[4]]}$

\subsection{Comparative treatment of 4-AA solutions by EAOPs}

To clarify whether PEF with a BDD anode is the most powerful EAOP for 4-AA removal, a comparative study with $50 \mathrm{mg} \mathrm{L}^{-1}$ drug solutions in the presence of $0.050 \mathrm{M} \mathrm{Na}_{2} \mathrm{SO}_{4}$ at $\mathrm{pH} 3.0$ (optimal for Fenton's reaction (2)) was performed by $\mathrm{EO}-\mathrm{H}_{2} \mathrm{O}_{2}$. EF, and $\mathrm{PEF}$, with only $15 \mathrm{mg} \mathrm{L}^{-1} \mathrm{Fe}^{2+}$ as catalyst for both Fenton-based methods, at a current density of $30 \mathrm{~mA} \mathrm{~cm}^{-2}$. A fast 4-AA removal by all these processes can be observed in Figure $2 \mathrm{a}$, disappearing after 40, 30, and 15 min of $E O-\mathrm{H}_{2} \mathrm{O}_{2}$, EF, and PEF, respectively. The drug decay by $E \mathrm{OO}-\mathrm{H}_{2} \mathrm{O}_{2}$ is due to the attack of $\mathrm{BDD}\left({ }^{\circ} \mathrm{OH}\right)$ formed from reaction (3). The additional $\cdot \mathrm{OH}$ generation from Fenton's reaction (2) explains the quicker 4-AA drop in EF, probably with a small contribution from the destruction of the unstable complex formed between Fe(III), produced from the above reaction, and 4-AA. The much larger enhancement of drug decay in PEF can then be mainly ascribed to other two concomitant factors: (i) the larger production of $\cdot \mathrm{OH}$, as a result of photolytic reaction (4), and (ii) the direct photolysis of the Fe(III)4-AA complex. The analysis of these concentration abatements obeyed a pseudo-first-order reaction kinetics, as shown in Figure $2 \mathrm{~b}$. From these plots, an increasing apparent rate constant $\left(k_{1}\right)$ of $0.145 \mathrm{~min}^{-1}\left(R^{2}=0.989\right)$ for $\mathrm{EO}-\mathrm{H}_{2} \mathrm{O}_{2}, 0.229 \mathrm{~min}^{-1}\left(R^{2}=0.988\right)$ for $\mathrm{EF}$, and $0.429 \mathrm{~min}^{-1}\left(R^{2}=0.983\right)$ for PEF, was obtained. This 
behavior is indicative of a steady drug removal in each treatment, suggesting a constant $\mathrm{BDD}\left({ }^{\circ} \mathrm{OH}\right)$ and/or ${ }^{\circ} \mathrm{OH}$ production, at least during the first stage.

Figure $2 \mathrm{c}$ depicts a slight gradual enhancement of TOC removal with time for the above series of experiments, attaining 49\%, 51\%, and $57 \%$ after 240 min of EO- $\mathrm{H}_{2} \mathrm{O}_{2}, \mathrm{EF}$, and PEF, respectively. These results confirm again the superiority of PEF over the other EAOPs. Nevertheless, its performance depends on the ability of $\cdot \mathrm{OH}$ production. This can be deduced from the higher TOC abatement, up to $67 \%$, achieved when a greater $\mathrm{Fe}^{2+}$ content of $30 \mathrm{mg} \mathrm{L}^{-1}$ was initially employed to treat the $50 \mathrm{mg} \mathrm{L}^{-1}$ drug solution (Figure 2c). This resulted from the acceleration of Fenton's reaction (2), yielding greater amounts of ${ }^{\circ} \mathrm{OH}$ as well as of $\mathrm{Fe}^{3+}$ at a given time that increased the quantity of photoactive products and caused a quicker photolysis. The optimization of the PEF process is then crucial to reach the highest efficiency.

The mineralization of the $50 \mathrm{mg} \mathrm{L}^{-1} 4-\mathrm{AA}$ solution is expected to transform its $N$ atoms mainly into nitrogenated ions. ${ }^{[19,21]}$ The analysis of the final solution with $30 \mathrm{mg} \mathrm{L}^{-1} \mathrm{Fe}^{2+}$ after 410 min of PEF, where $97 \%$ TOC was abated, revealed the release of 0.78 $\mathrm{mM} \mathrm{NH}_{4}{ }^{+}$ion $(82.5 \%$ of initial $\mathrm{N})$ and $0.24 \mathrm{mM} \mathrm{NO}_{3}{ }^{-}$ion $(7.3 \%$ of initial $\mathrm{N}$ ). From these data, the overall mineralization reaction for the drug, considering $\mathrm{NH}_{4}{ }^{+}$as the pre-eminent nitrogenated ion, can be written as follows with an $n$-value of 46 :

$\mathrm{C}_{11} \mathrm{H}_{13} \mathrm{~N}_{3} \mathrm{O}+21 \mathrm{H}_{2} \mathrm{O} \rightarrow 11 \mathrm{CO}_{2}+3 \mathrm{NH}_{4}^{+}+43 \mathrm{H}^{+}+46 \mathrm{e}^{-}$

This allowed the estimation of the percentage of mineralization current efficiency (MCE) for each assay from equation (8): ${ }^{[19]}$

$\operatorname{MCE}(\%)=\frac{n F V_{S} \Delta \mathrm{TOC}}{4.32 \times 10^{7} \mathrm{mIt}} 100$

where $F$ is the Faraday constant, $V_{s}$ is the solution volume (in $L$ ), $\triangle T O C$ is the change of TOC (in $\mathrm{mg} \mathrm{L}^{-1}$ ), $4.32 \times 10^{7}$ is a conversion factor ( $3600 \mathrm{~s} \mathrm{~h}^{-1} \times 12,000 \mathrm{mg} \mathrm{C} \mathrm{mol}^{-1}$ ), $m=11$ is the number of carbon atoms of $4-A A, I$ is the current (in A), and $t$ is the electrolysis time (in h).

2.3 Optimization of the PEF process by response surface methodology

\subsubsection{Central composite desing (CCD) model}

The influence of the main independent variables on several characteristic parameters of the PEF treatment of 4-AA in 0.050 $\mathrm{M} \mathrm{Na} \mathrm{SO}_{4}$ solutions at $\mathrm{pH} 3.0$ was assessed with a CCD model based on response surface methodology. The four selected independent variables were: current density $\left(X_{1}\right)$, initial $\mathrm{Fe}^{2+}$ concentration $\left(X_{2}\right)$, initial 4-AA concentration $\left(X_{3}\right)$, and electrolysis
Table 1. Levels of the $2^{4}$ central composite design (CCD) for the PEF treatment of $4-A A$.

\begin{tabular}{cccccc}
\hline Variable & \multicolumn{5}{c}{ Level } \\
\cline { 2 - 6 } & -2 & -1 & 0 & +1 & +2 \\
\hline $\begin{array}{c}\text { Current density } \\
\left(\mathrm{mA} \mathrm{cm}^{-2}\right), \mathrm{X}_{1}\end{array}$ & 10.0 & 32.5 & 55.0 & 77.5 & 100.0 \\
$\begin{array}{c}{\left[\mathrm{Fe}^{2+}\right]\left(\mathrm{mg} \mathrm{L}^{-1}\right), \mathrm{X}_{2}} \\
\left.\text { [4-AA] (mg L }{ }^{-1}\right), \mathrm{X}_{3}\end{array}$ & 2.0 & 17.25 & 32.5 & 47.75 & 63.0 \\
$\begin{array}{c}\text { Time (min): \% 4-AA } \\
\text { degradation, } \mathrm{X}_{4}\end{array}$ & 1 & 3 & 5 & 7 & 175.0 \\
$\begin{array}{c}\text { Time (min): \% 4-AA } \\
\text { mineralization } \\
\text { and \% MCE, } \mathrm{X}_{4}\end{array}$ & 10 & 50 & 90 & 130 & 170 \\
\hline
\end{tabular}

time $\left(X_{4}\right)$. A $2^{4}$ factorial design was then followed, with a total of 27 trials involving 16 cube points, 8 axial points, and a triplicate at the center point, and the experimental matrix was generated with the Statistica 10 software (StatSoft, Tulsa, USA). Table 1 collects the experimental levels and ranges chosen for the fourindependent variables to evaluate the performance from the percentages of 4-AA degradation, 4-AA mineralization, and MCE. Based on Figure 2, short times were selected for the former percentage, being much longer for the two latter ones. Table 2 summarizes the observed results for the twenty-seven selected assays, whose experimental parameters are listed in Table S1.

From the response surface methodology, the following secondorder polynomial equation was deduced to describe the interaction between independent and dependent variables: ${ }^{[14,47]}$

$Y=\beta_{0}+\sum_{\mathrm{i}=1}^{\mathrm{k}} \beta_{\mathrm{i}} X_{\mathrm{i}}+\sum_{1 \leq i \leq j}^{k} \beta_{\mathrm{ij}} X_{\mathrm{i}} X_{\mathrm{j}}+\sum_{i=1}^{\mathrm{k}} \beta_{\mathrm{ii}} X_{\mathrm{i}}^{2}$

where $\mathrm{k}$ represents the number of variables, $Y$ denotes the dependent variable (percentage of 4-AA degradation, 4-AA mineralization, or MCE), and $\beta_{0}, \beta_{\mathrm{i}}, \beta_{\mathrm{ij}}$, and $\beta_{\mathrm{ii}}$ denote the regression coefficients for the linear and quadratic effects related to the linear $X_{\mathrm{i}}$, quadratic $X_{\mathrm{i}}^{2}$, and $X_{\mathrm{i}} X_{\mathrm{j}}$ interaction terms.

Table 2 also collects the predicted responses generated from equation (9) for the arithmetic averages of the three dependent variables with $\pm 95 \%$ confidence limits. Figures S1a, S1c, and S1e depict the excellent linear predicted-observed values plots obtained for the percentages of 4-AA degradation, 4-AA mineralization, and MCE, respectively. These linear relationships present good $R^{2}$-values between 0.963 and 0.975 , as well as adjusted correlation coefficients $\left(R^{2}{ }_{\text {adj }}\right)$ between 0.919 and 0.945 . The model was then validated from the good accordance between the predicted and observed values. ${ }^{[14,47]}$ Moreover, Figures S1b, S1d, and S1f evidence that the corresponding expected normal value vary linearly with the residuals, i.e., the difference between the predicted and observed values. This informs about the sturdiness of the three mathematic models, following a normal distribution and allowing describing appropriately the responses. ${ }^{[47-49]}$ 
Table 2. Observed and predicted values of the percentage of degradation, mineralization, and mineralization current efficiency, obtained for the PEF treatment of 4-AA using different combinations of the $2^{4} \mathrm{CCD}$. The experimental parameter for each level in each trial is given in Table S1.

\begin{tabular}{|c|c|c|c|c|c|c|}
\hline \multirow[t]{2}{*}{ Trial } & \multicolumn{2}{|c|}{$\%$ 4-AA degradation } & \multicolumn{2}{|c|}{ \% 4-AA mineralization } & \multicolumn{2}{|c|}{$\% \mathrm{MCE}$} \\
\hline & Obs. & Pred. & Obs. & Pred. & Obs. & Pred. \\
\hline 1 & 31 & 27 & 11 & 10 & 4.5 & 5.0 \\
\hline 2 & 64 & 61 & 24 & 24 & 2.4 & 2.8 \\
\hline 3 & 14 & 12 & 4.0 & 5.0 & 4.7 & 6.3 \\
\hline 4 & 56 & 52 & 15 & 13 & 2.2 & 3.2 \\
\hline 5 & 45 & 44 & 14 & 15 & 5.8 & 7.5 \\
\hline 6 & 78 & 75 & 32 & 35 & 4.9 & 2.7 \\
\hline 7 & 18 & 15 & 12 & 10 & 12 & 11 \\
\hline 8 & 55 & 52 & 25 & 24 & 9.8 & 9.0 \\
\hline 9 & 47 & 44 & 11 & 13 & 2.4 & 3.8 \\
\hline 10 & 70 & 67 & 30 & 31 & 2.4 & 2.5 \\
\hline 11 & 27 & 23 & 15 & 11 & 5.8 & 4.7 \\
\hline 12 & 57 & 52 & 24 & 23 & 3.7 & 2.6 \\
\hline 13 & 79 & 76 & 19 & 20 & 3.8 & 2.8 \\
\hline 14 & 99 & 95 & 45 & 44 & 3.2 & 2.1 \\
\hline 15 & 43 & 40 & 16 & 17 & 6.3 & 6.4 \\
\hline 16 & 70 & 67 & 35 & 35 & 5.4 & 4.8 \\
\hline 17 & 18 & 23 & 11 & 11 & 12 & 10 \\
\hline 18 & 46 & 54 & 26 & 26 & 2.9 & 5.7 \\
\hline 19 & 18 & 27 & 16 & 17 & 3.0 & 4.4 \\
\hline 20 & 52 & 57 & 35 & 34 & 6.0 & 1.9 \\
\hline 21 & 85 & 91 & 28 & 25 & 1.8 & 1.9 \\
\hline 22 & 40 & 47 & 9.0 & 12 & 3.8 & 5.4 \\
\hline 23 & 17 & 22 & 2.0 & 3.0 & 9.1 & 7.1 \\
\hline 24 & 75 & 82 & 35 & 35 & 3.2 & 6.4 \\
\hline 25 & 48 & 47 & 20 & 20 & 4.1 & 6.3 \\
\hline 26 & 48 & 47 & 18 & 20 & 4.1 & 6.3 \\
\hline 27 & 46 & 47 & 21 & 20 & 4.5 & 6.3 \\
\hline
\end{tabular}

2.3.2 4-AA degradation percentage

The Pareto chart of Figure 3a obtained for the percentage of 4AA degradation highlights the statistical significance $(p>0.05)$ of
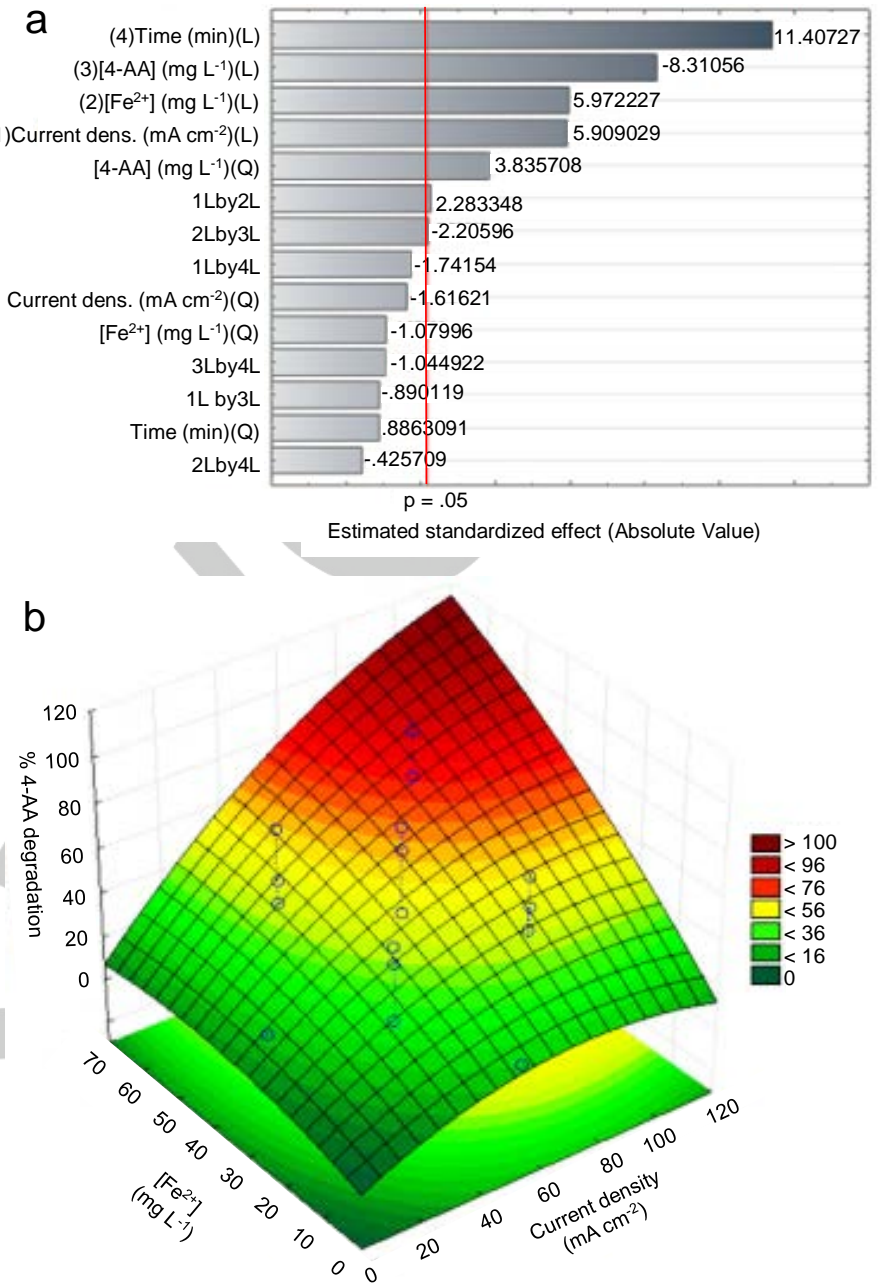

C

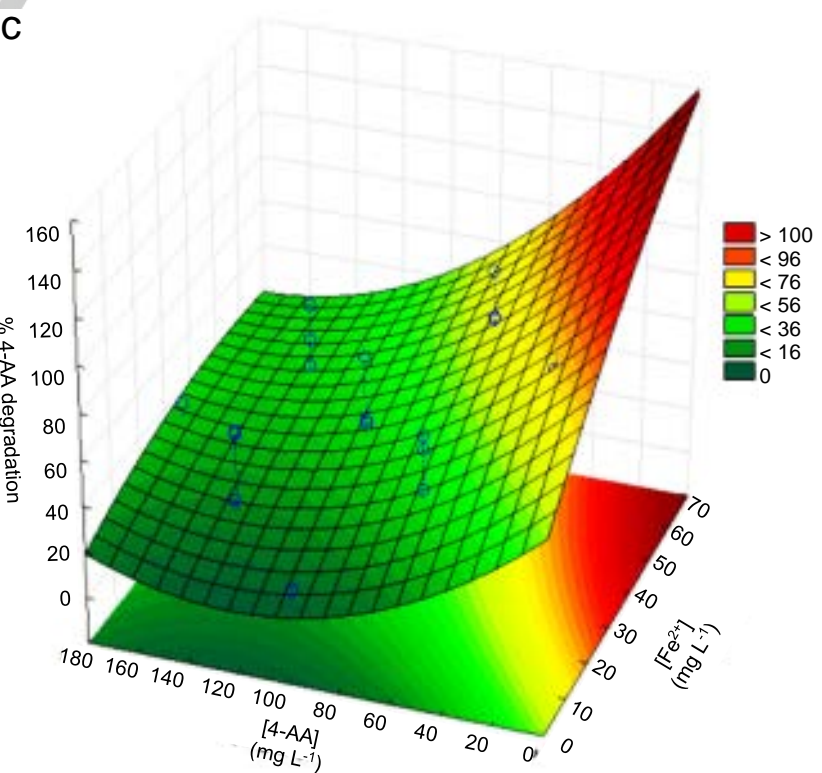

Figure 3. (a) Pareto chart for the percentage of 4-AA degradation. Response surface plots for such percentage vs.: (b) current density and $\mathrm{Fe}^{2+}$ content at $62.5 \mathrm{mg} \mathrm{L}^{-1} \mathrm{drug}$, and (c) $\mathrm{Fe}^{2+}$ and 4-AA concentration at current density of 77.5 $\mathrm{mA} \mathrm{cm} \mathrm{cm}^{-2}$, after $3 \mathrm{~min}$ of PEF treatment. 
the four linear independent parameters, the squared initial drug concentration, and the interactions of initial $\mathrm{Fe}^{2+}$ content with current density (1Lby2L) and initial 4-AA concentration (2Lby3L). The following empirical equation was derived from the model, only considering the terms that are statistically significant:

$Y_{\% \text { degr }}=47.3+15.6 X_{1}+15.7 X_{2}-21.9 X_{3}+10.7 X_{3}{ }^{2}$

$+30 X_{4}+7.4 X_{1} X_{2}-7 X_{2} X_{3}$

where $Y_{\% \text { degr }}$ represents the response of the percentage of 4-AA degradation, whereas $X_{1}, X_{2}, X_{3}$, and $X_{4}$ denote the linear variables current density, initial $\mathrm{Fe}^{2+}$ concentration, initial 4-AA content, and time, respectively.

It is important to pay attention to the signs of the regression coefficients, since a positive value is indicative of an improvement of the response with increasing the dependent variable, whereas the opposite trend occurs for a negative coefficient. For the interacted variables, positive coefficients reveal a synergistic effect, whereas negative ones reveal an antagonistic influence between them. ${ }^{[50,51]}$ According to equation (10), these criteria evidence an increase in the percentage of drug degradation with increasing current density, initial $\mathrm{Fe}^{2+}$ concentration, and time. This agrees with the concomitant production of greater quantities of $\mathrm{BDD}\left({ }^{\circ} \mathrm{OH}\right)$ from reaction (3) at high current, as well as of ${ }^{\circ} \mathrm{OH}$ by accelerating reaction (1), leading to higher amounts of $\mathrm{H}_{2} \mathrm{O}_{2}$ that enhance Fenton's reaction (2) ${ }^{[19,21]}$ The quicker $\mathrm{Fe}^{3+}$ reduction to $\mathrm{Fe}^{2+}$ at the cathode also favors the latter reaction. ${ }^{[20]}$ Independently, Fenton's reaction (2) can be upgraded when greater $\mathrm{Fe}^{2+}$ amounts are added to the medium, with faster production of $[\mathrm{Fe}(\mathrm{OH})]^{2+}$ that can photogenerate more $\cdot \mathrm{OH}$ from reaction (4). ${ }^{[19,23]}$ The progressive degradation of drug molecules explains the positive effect of time since longer time allows their gradual oxidation. Conversely, the highly negative coefficient related to 4-AA concentration accounted for a more rapid abatement of smaller amounts of drug, since the same content of oxidizing agents are expected to be formed under analogous conditions, thus limiting the molecule destruction. ${ }^{[21,23]}$ However, a positive coefficient was determined for the squared 4-AA concentration, in agreement with a rotatability model. ${ }^{[52,53]}$

A synergistic effect can be observed in equation (10) for the interaction between current density and initial $\mathrm{Fe}^{2+}$ concentration, with positive coefficient. This important feature can be easily deduced from Table 2 for $62.5 \mathrm{mg} \mathrm{L}^{-1}$ drug electrolysis at $3 \mathrm{~min}$, attaining $31 \%$ degradation at $32.5 \mathrm{~mA} \mathrm{~cm}^{-2}$ with $17.25 \mathrm{mg} \mathrm{L}^{-1} \mathrm{Fe}^{2+}$, which grew to $79 \%$ by increasing both variables to $77.5 \mathrm{~mA} \mathrm{~cm}^{-2}$ and $47.75 \mathrm{mg} \mathrm{L}^{-1} \mathrm{Fe}^{2+}$. The negative coefficient of the relationship of initial $\mathrm{Fe}^{2+}$ and 4-AA contents informs about their antagonistic effect, causing a loss of percentage degradation when both parameters grew simultaneously. For example, after 3 min at 77.5 $\mathrm{mA} \mathrm{cm}{ }^{-2}$, the 4-AA removal reached $47 \%$ at $17.25 \mathrm{mg} \mathrm{L}^{-1} \mathrm{Fe}^{2+}$ and $62.5 \mathrm{mg} \mathrm{L}^{-1}$ drug, dropping to $43 \%$ when the variables increased to $47.75 \mathrm{mg} \mathrm{L}^{-1} \mathrm{Fe}^{2+}$ and $137.5 \mathrm{mg} \mathrm{L}^{-1}$ drug. Figures $3 \mathrm{~b}$ and $\mathrm{c}$ show the response surfaces generated for both pairs of independent variables at 3 min of treatment. For $62.5 \mathrm{mg} \mathrm{L}^{-1} 4-\mathrm{AA}$, Figure $3 \mathrm{~b}$ depicts a small drug removal operating either at the lowest current density of $10.0 \mathrm{~mA} \mathrm{~cm}{ }^{-2}$ or the smallest $\mathrm{Fe}^{2+}$ concentration of $17.25 \mathrm{mg} \mathrm{L}^{-1}$, with a drastic enhancement upon increase of both variables as a result of the gradual acceleration of oxidants production, as stated above. A high degradation of $79 \%$ was already attained at $77.5 \mathrm{~mA} \mathrm{~cm}^{-2}$ and $47.75 \mathrm{mg} \mathrm{L}^{-1} \mathrm{Fe}^{2+}$. Considering the latter current density, the opposite influence of $\mathrm{Fe}^{2+}$ and 4-AA contents on degradation percentage can be seen in Figure 3c, since it was upgraded with raising the former variable but decreased with increasing the latter one. For example, at the highest drug concentration of $137.5 \mathrm{mg} \mathrm{L}^{-1}, 27 \%$ degradation was achieved using $17.25 \mathrm{mg} \mathrm{L}^{-1} \mathrm{Fe}^{2+}$, increasing to $43 \%$ at higher $47.75 \mathrm{mg} \mathrm{L}^{-1} \mathrm{Fe}^{2+}$. In contrast, a much greater degradation of $79 \%$ was reached at a lower drug content of $62.5 \mathrm{mg} \mathrm{L}^{-1}$ using the latter $\mathrm{Fe}^{2+}$ value. A look to Tables 2 and S1 confirms that the best degradation conditions were attained at $77.5 \mathrm{~mA} \mathrm{~cm}^{-2}, 47.75 \mathrm{mg}$ $\mathrm{L}^{-1} \mathrm{Fe}^{2+}$, and $62.5 \mathrm{mg} \mathrm{L}^{-1} 4-\mathrm{AA}$, with $99 \%$ drug removal in $7 \mathrm{~min}$.

\subsubsection{4-AA mineralization percentage}

When the percentage of 4-AA mineralization $\left(Y_{\% \text { miner }}\right)$ in the PEF treatment was considered, the four linear variables, the squared initial $\mathrm{Fe}^{2+}$ concentration, and the interactions between time and initial $\mathrm{Fe}^{2+}(2 \mathrm{Lby} 4 \mathrm{~L})$ or initial 4-AA (3Lby4L) contents presented a p-value $>0.05$, then resulting statistically significant, as can be seen in the corresponding Pareto chart of Figure 4a. The generated empirical model for $Y_{\% \text { miner }}$ expressed as a function of the different $X_{i}$ terms above defined, only considering the terms that are statistically significant, can be expressed as follows:

$Y_{\% \text { miner }}=19.7+7.3 X_{1}+8.5 X_{2}+3.1 X_{2}^{2}-6.5 X_{3}$

$+16.17 X_{4}+3 X_{2} X_{4}-3 X_{3} X_{4}$

According to this equation, increasing current density, the initial $\mathrm{Fe}^{2+}$ concentration and its square, as well as time improved the mineralization of the drug solutions, as revealed by the positive coefficients. This is the same behavior described above for the percentage of degradation and it is related to the gradually greater production of $\mathrm{BDD}\left({ }^{\circ} \mathrm{OH}\right)$ and ${ }^{\circ} \mathrm{OH}$ from reactions (1)-(4) as the values of these variables were increased. Furthermore, the quicker generation of photoactive products accelerated their photodecomposition under UVA illumination, upgrading the mineralization process. The positive coefficient of the quadratic $\mathrm{Fe}^{2+}$ concentration agrees again with the prediction of a rotatability model. Longer time was also beneficial. However, $\mathrm{Fe}^{2+}$ reached a maximum concentration, since its excess causes its destruction with ${ }^{\circ} \mathrm{OH}$ to form $\mathrm{Fe}^{3+}$ and $\mathrm{OH}^{-}{ }^{-[19-23]}$ The opposite trend occurred for 4-AA concentration, with a negative coefficient in equation (11), in agreement with the limited formation of oxidizing species under given conditions.

Equation (11) shows a synergistic effect of the initial $\mathrm{Fe}^{2+}$ content and time, presupposing greater mineralization with the rise of both 
variables. For example, using $77.5 \mathrm{~mA} \mathrm{~cm}^{-2}$ and $62.5 \mathrm{mg} \mathrm{L}^{-1} \mathrm{drug}$, $30 \%$ mineralization was attained after 130 min of electrolysis with $17.24 \mathrm{mg} \mathrm{L}^{-1} \mathrm{Fe}^{2+}$, which increased to $45 \%$ at the same time with $47.75 \mathrm{mg} \mathrm{L}^{-1} \mathrm{Fe}^{2+}$ (Table 2). On the other hand, the initial 4-AA concentration vs. time relationship presented an antagonistic effect with negative coefficient. The effects of the above synergistic and antagonistic interactions on the mineralization percentage can be visualized in the corresponding response surfaces presented in Figures $4 \mathrm{~b}$ and $\mathrm{c}$. The best experimental conditions were: $77.5 \mathrm{~mA} \mathrm{~cm}^{-2}, 47.75 \mathrm{mg} \mathrm{L}^{-1} \mathrm{Fe}^{2+}$, and $62.5 \mathrm{mg} \mathrm{L}^{-}$ ${ }^{1} 4$-AA, which yielded up to $96 \%$ mineralization by extending the electrolysis to $410 \mathrm{~min}$. This demonstrates the high oxidation ability of PEF to destroy all the oxidation products of the drug due to the combined action of $\mathrm{BDD}\left({ }^{\circ} \mathrm{OH}\right),{ }^{\bullet} \mathrm{OH}$, and UVA light.

\subsubsection{Percentage of mineralization current efficiency}

Regarding the percentage of MCE (Y\%MCE), the Pareto chart of Figure $5 \mathrm{a}$ evidences that the four variables, the quadratic current density, and the relationship between current density and initial $\mathrm{Fe}^{2+}$ concentration (1LbyL2) show statistical significance $(p>$ $0.05)$. The following equation represents the effect of the variables $X_{\mathrm{i}}$ above defined on $Y_{\% \mathrm{MCE}}$, only considering the terms that are statistically significant:

$Y_{\% \mathrm{MCE}}=4.28-2.67 X_{1}+1.58 X_{1}^{2}+2.34 X_{2}$

$+2 X_{3}-1.89 X_{4}-1.74 X_{1} X_{2}$

The negative coefficients of current density and time indicate that they are inversely proportional to the percentage of $\mathrm{MCE}$, causing a decrease of this parameter when those variables increased. This tendency is in contrast to that of the quadratic current density, as well as initial $\mathrm{Fe}^{2+}$ and drug concentrations, with positive coefficients. This can be related to the enhancement of the parasitic reactions involving $\operatorname{BDD}\left({ }^{\circ} \mathrm{OH}\right)$ and ${ }^{\bullet} \mathrm{OH}$, with loss of MCE in the former case, whereas in the second one, the deceleration of such reactions allows the greater production of oxidizing species that upgrade the destruction of organic pollutants. ${ }^{[19,21,23]}$ Some examples from the data listed in Tables 2 and S1 can justify the trends given by equation (12). At $32.5 \mathrm{~mA} \mathrm{~cm}-2,5.0 \% \mathrm{MCE}$ was obtained at $50 \mathrm{~min}$ for the treatment of $62.5 \mathrm{mg} \mathrm{L}^{-1}$ with 17.25 $\mathrm{mg} \mathrm{L}^{-1} \mathrm{Fe}^{2+}$. When the current density grew to $77.5 \mathrm{~mA} \mathrm{~cm}^{-2}$, the MCE value decreased to $3.8 \%$, which decayed to $2.5 \%$ at a longer time of $130 \mathrm{~min}$. Conversely, the MCE increased to $11 \%$ operating with $47.75 \mathrm{mg} \mathrm{L}^{-1} \mathrm{Fe}^{2+}$, and to $6.3 \%$ at $137.5 \mathrm{mg} \mathrm{L}^{-1} 4-\mathrm{AA}$, always maintaining the values of the other variables.

An antagonistic relationship between current density and initial $\mathrm{Fe}^{2+}$ concentration is also shown in equation (12). This can be observed in the response surface of the percentage of MCE with both variables, as presented in Fig. $5 b$, where its value increased with decreasing current density and raising $\mathrm{Fe}^{2+}$ content. For the best degradation and mineralization conditions $\left(77.5 \mathrm{~mA} \mathrm{~cm}{ }^{-2}\right.$, $47.75 \mathrm{mg} \mathrm{L}^{-1} \mathrm{Fe}^{2+}$, and $62.5 \mathrm{mg} \mathrm{L}^{-1} \mathrm{drug}$ ), discrete observed and
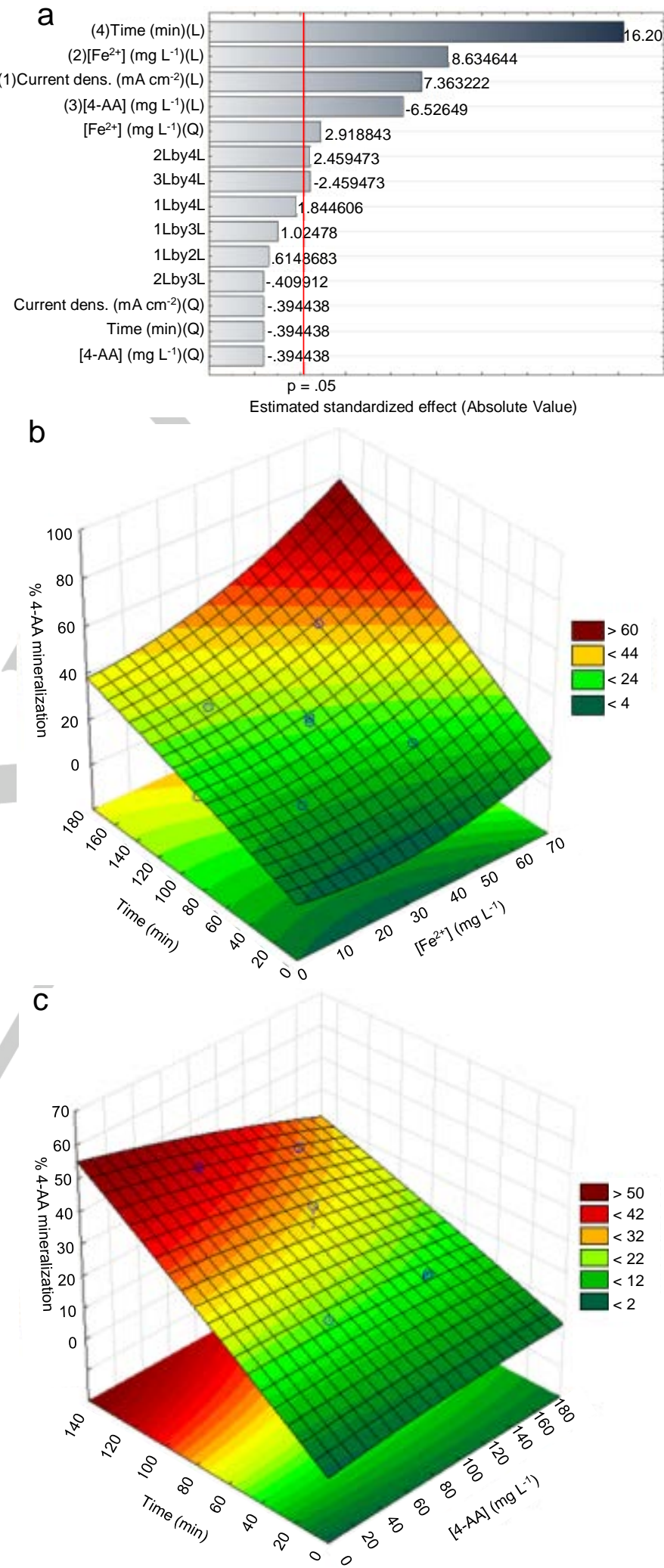

Figure 4. (a) Pareto chart for the percentage of 4-AA mineralization. Response surface plot for this percentage vs.: (b) $\mathrm{Fe}^{2+}$ content and time at $62.5 \mathrm{mg} \mathrm{L}^{-1}$ drug, and (c) 4-AA concentration and time at $47.75 \mathrm{mg} \mathrm{L}^{-1} \mathrm{Fe}^{2+}$, upon PEF treatment at current density of $77.5 \mathrm{~mA} \mathrm{~cm}^{-2}$. 
a

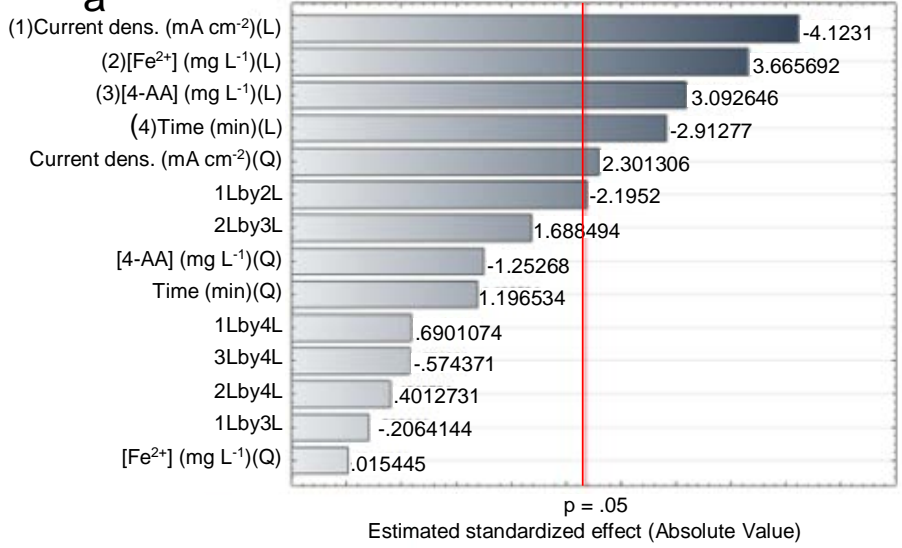

b

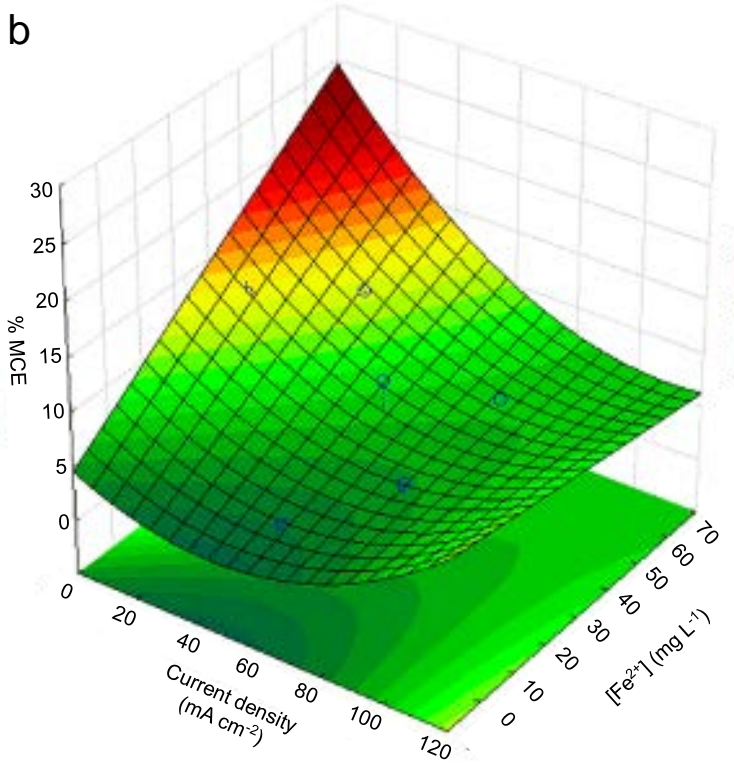

Figure 5. (a) Pareto chart for the percentage of mineralization current efficiency. (b) Response surface plot for such percentage vs. $\mathrm{Fe}^{2+}$ concentration and current density, upon PEF treatment of solutions with $137.5 \mathrm{mg} \mathrm{L}^{-1}$ drug for 50 $\min$.

predicted MCE values of $3.2 \%$ and $2.1 \%$, respectively, were determined at $130 \mathrm{~min}$ (Table 2 ) because of the relatively high applied current density.

\subsection{PEF treatment of 4-AA in a municipal secondary effluent}

Once established the best operational variables $\left(62.5 \mathrm{mg} \mathrm{L}^{-1} 4-\mathrm{AA}\right.$, current density of $77.5 \mathrm{~mA} \mathrm{~cm}^{-2}$ and $47.75 \mathrm{mg} \mathrm{L}^{-1} \mathrm{Fe}^{2+}$ ) for the PEF treatment of 4-AA in pure water with $0.050 \mathrm{M} \mathrm{Na}_{2} \mathrm{SO}_{4}$, the study was extended under these conditions to a municipal secondary effluent to clarify the effect of its components, natural organic matter (NOM) and inorganic salts, on the process performance. Table S2 collects the physicochemical characteristics of this effluent of $\mathrm{pH} 7.06$, TOC of $10.5 \mathrm{mg} \mathrm{L}^{-1}$ and $35.6 \mathrm{mg} \mathrm{L}^{-1} \mathrm{Cl}^{-}$as pre-eminent anion. The presence of $\mathrm{Cl}^{-}$makes the oxidation process more complex because it is oxidized to active chlorine $\left(\mathrm{Cl}_{2} / \mathrm{HClO}\right)$ at the BDD surface, which is subsequently transformed into chlorate and perchlorate ions. ${ }^{[21,23,33]}$ Competition between active chlorine, $\mathrm{BDD}\left({ }^{\circ} \mathrm{OH}\right)$ and ${ }^{\circ} \mathrm{OH}$ to attack the organic pollutants with generation of chloroderivatives is then expected.
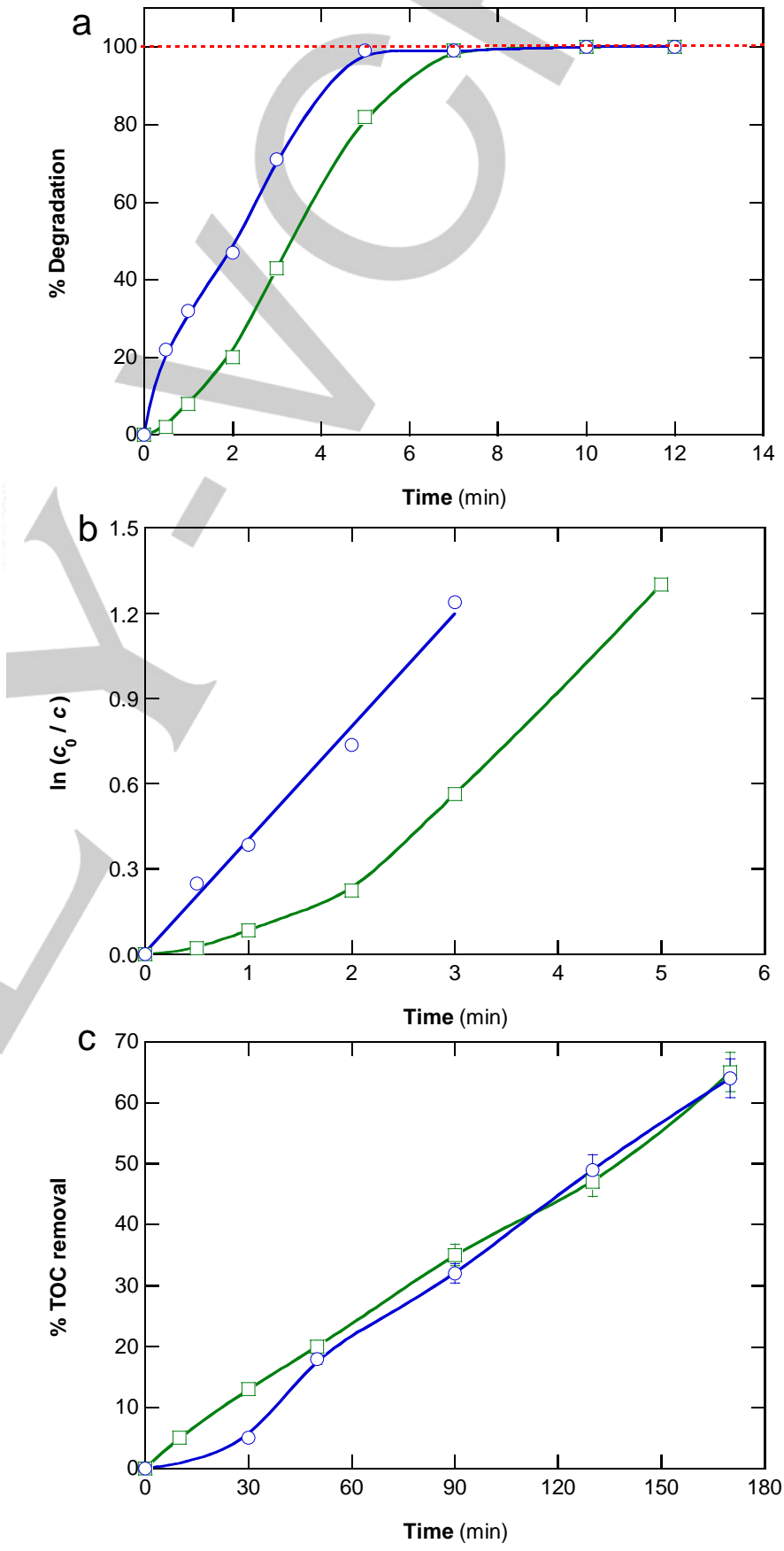

Figure 6. (a) Percentage of degradation vs. electrolysis time for the PEF treatment of $62.5 \mathrm{mg} \mathrm{L}^{-1} 4-\mathrm{AA}$ in $(\bigcirc)$ pure water $\left(40.6 \mathrm{mg} \mathrm{L}^{-1} \mathrm{TOC}\right)$ and $(\square)$ spiked into municipal secondary wastewater (51.1 $\left.\mathrm{mg} \mathrm{L}^{-1} \mathrm{TOC}\right)$ at $\mathrm{pH} 3.0,25^{\circ} \mathrm{C}$ and $77.5 \mathrm{~mA} \mathrm{~cm}^{-2}$. In both matrices, $0.050 \mathrm{M} \mathrm{Na}_{2} \mathrm{SO}_{4}$ and $47.75 \mathrm{mg} \mathrm{L}^{-1} \mathrm{Fe}^{2+}$ were added. (b) Pseudo-first-order kinetic analysis of the above trials. (c) Percentage of TOC removal for the same assays. 


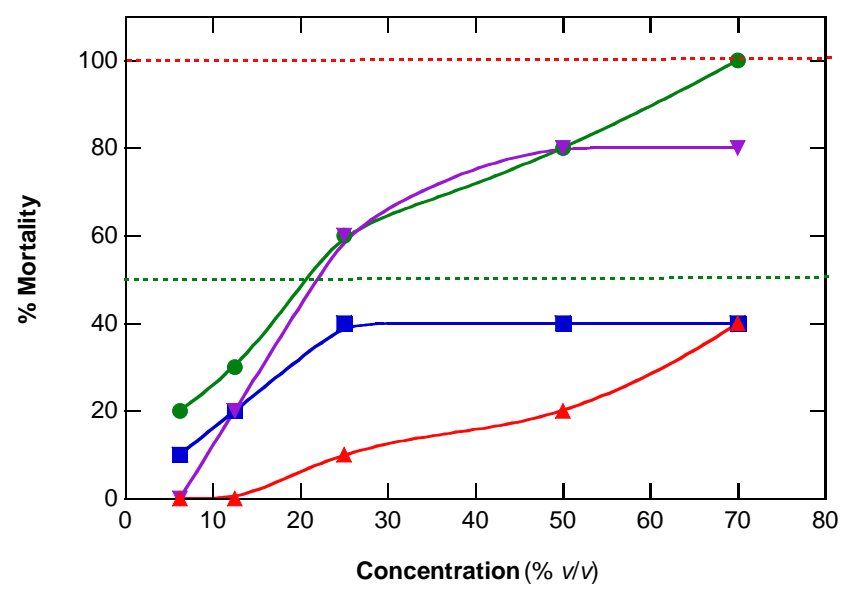

Figure 7. (a) Change of Artemia salina mortality with the concentration of diluted aliquots of $(\square)$ the raw municipal secondary effluent, $(\bullet)$ solutions of $62.5 \mathrm{mg}$ $\mathrm{L}^{-1}$ of $4-\mathrm{AA}$ spiked into that matrix, and samples withdrawn after $(\boldsymbol{\nabla}) 7 \mathrm{~min}$ and (A) 130 min of PEF treatment of the drug solution in the effluent.

To operate in PEF under the same experimental conditions with both aqueous matrices, $0.050 \mathrm{M} \mathrm{Na}_{2} \mathrm{SO}_{4}$ was added to the municipal secondary effluent and its $\mathrm{pH}$ was adjusted to 3.0 with $\mathrm{H}_{2} \mathrm{SO}_{4}$. In this way, its conductivity was about $11 \mathrm{mS} \mathrm{cm}^{-1}$, very close to that of pure water with $0.050 \mathrm{M} \mathrm{Na}_{2} \mathrm{SO}_{4}$. After spiking the drug and $\mathrm{Fe}^{2+}$ to reach $62.5 \mathrm{mg} \mathrm{L}^{-1}$ and $47.75 \mathrm{mg} \mathrm{L}^{-1}$, respectively, the PEF treatment of the conditioned municipal secondary effluent at $77.5 \mathrm{~mA} \mathrm{~cm}^{-2}$ yielded a similar cell voltage to that of the pure water matrix. Figure $6 \mathrm{a}$ shows a slightly slower 4-AA abatement in the former matrix because of the simultaneous oxidation of the drug and NOM with the oxidizing agents, although in both cases $>99 \%$ removal was achieved after $7 \mathrm{~min}$. The concentration decay in pure water clearly followed a pseudo-firstorder reaction kinetics (Figure 6b), with $k_{1}=0.393 \mathrm{~min}^{-1}\left(R^{2}=\right.$ 0.991), whereas this behavior was not verified using the conditioned municipal secondary effluent due to the consumption of oxidants in NOM degradation. This latter hypothesis was confirmed from the analogous TOC removal percentage obtained using both matrices, as depicted in Fig. 6c. Since 40.6 and 51.1 $\mathrm{mg} \mathrm{L}^{-1}$ TOC were initially contained in pure water and municipal secondary effluent, respectively, one can deduce that after 170 min of electrolysis with $65 \%$ TOC reduction, an amount of $26.4 \mathrm{vs.}$ $33.2 \mathrm{mg} \mathrm{L}^{-1}$ TOC was destroyed during the PEF treatments. The superior quantity of TOC removed in the latter medium corroborated the occurrence of NOM mineralization, which seems to affect rather slightly the drug mineralization. This ensures the good ability of PEF to mineralize 4-AA in municipal secondary effluents.

\subsection{Acute toxiciy assessment}

The measurement of the solution toxicity during PEF treatment is essential to limit its duration before a potential combination with a more inexpensive process. ${ }^{[23]}$ With this purpose, the larvae of the microcrustacean Artemia salina has been widely used, because it is easy to handle and shows a large acute toxicity to persistent pollutants. ${ }^{[54,55]}$ The mortality profile of this organism was then employed to assess the toxicity of: (i) the raw municipal secondary effluent, (ii) a solution of $62.5 \mathrm{mg} \mathrm{L}^{-1}$ 4-AA prepared with that wastewater, and (iii) the resulting samples after 7 and $130 \mathrm{~min}$ of PEF treatment under the best operation conditions. The residual $\mathrm{H}_{2} \mathrm{O}_{2}$ in the two latter samples was destroyed by dropwise addition of a solution with $1 \mathrm{~g} \mathrm{~L}^{-1}$ catalase.

Figure 7 highlights that the secondary effluent was not acutely toxic, since it did not promote a larval mortality superior to the threshold value of $50 \%$, In contrast, a very high larvae mortality can be observed for the same wastewater contaminated with 4AA. The median lethal concentration at $50 \%$ larvae mortality ( $\left.L C_{50}\right)$ can be converted into toxic units (TU) in the 1-10 range from the relationship $\mathrm{TU}=\left(1 / \mathrm{LC}_{50}\right) \times 100 .{ }^{[56]}$ Thus, a solution with $62.5 \mathrm{mg} \mathrm{L}^{-1}$ 4-AA spiked into the municipal secondary effluent exhibited an $\mathrm{LC}_{50}=26.8 \mathrm{~mL} \mathrm{~mL}^{-1}$ and $\mathrm{TU}=3.8$. Similarly, Figure 7 reveals that, after 7 min of PEF, i.e., when the target pollutant was completely removed, the resulting wastewater still presented acute toxicity with $\mathrm{LC}_{50}=38.6 \mathrm{~mL} \mathrm{~mL}^{-1}$ and $\mathrm{TU}=2.6$. This means that the initially generated oxidation products were still toxic. However, they evolved to much less toxic molecules, as deduced from the fact that, after 130 min of PEF, less than $50 \%$ of larvae population was killed (Figure 7). These findings indicate that PEF allows producing non-toxic wastewater upon treatment of water contaminated with 4-AA, at relatively short electrolysis time. Such detoxified wastewater may be further treated by a low cost biological process.

\section{Conclusions}

It has been shown that PEF process with a BDD/air-diffusion cell under irradiation with a 4-W UVA lamp has greater oxidation ability than EF and EO- $\mathrm{H}_{2} \mathrm{O}_{2}$ for the removal of 4-AA in $0.050 \mathrm{M}$ $\mathrm{Na}_{2} \mathrm{SO}_{4}$ at $\mathrm{pH}$ 3.0 This is due to the synergistic oxidative action of UVA photons and generated $\mathrm{BDD}\left({ }^{\circ} \mathrm{OH}\right)$ and ${ }^{\circ} \mathrm{OH}$. The formation of an unstable Fe(III)-4-AA complex with 1:2 molar ratio and $K=$ $6.2 \times 10^{6} \mathrm{M}^{-1}$ has been evidenced. A $2^{4} \mathrm{CCD}$ model, with current density, initial $\mathrm{Fe}^{2+}$ and drug concentrations, and time as independent variables provided an excellent description of the behavior of the percentages of 4-AA degradation, 4-AA mineralization, and MCE achieved in PEF. The best experimental conditions were: $77.5 \mathrm{~mA} \mathrm{~cm}{ }^{-2}, 47.75 \mathrm{mg} \mathrm{L}^{-1} \mathrm{Fe}^{2+}$, and $62.75 \mathrm{mg}$ $\mathrm{L}^{-1}$ 4-AA, giving rise to $99 \%$ degradation at $7 \mathrm{~min}$ and $45 \%$ mineralization at $130 \mathrm{~min}$, along with an MCE of $3.2 \%$. By extending the treatment up to $410 \mathrm{~min}$, the solution attained $96 \%$ mineralization. The application of these experimental conditions to the PEF treatment of the drug spiked into a more complex matrix, such as a municipal secondary effluent with $0.050 \mathrm{M}$ $\mathrm{Na}_{2} \mathrm{SO}_{4}$ at $\mathrm{pH} 3.0$, revealed a TOC removal of $65 \%$ after $240 \mathrm{~min}$, similar to the value obtained in pure water. It has been shown that PEF treatment allows the detoxification of urban wastewater polluted with 4-AA in a short time. 


\section{Experimental Section}

Solutions of 4-AA (99\% purity, Sigma-Aldrich) in pure water (resistivity > $18.2 \mathrm{M} \Omega \mathrm{cm}$, Millipore Milli-Q) were adjusted to $\mathrm{pH} 3.0$ with analytical grade $\mathrm{H}_{2} \mathrm{SO}_{4}$ purchased from Vetec Quimica Fina. For the electrolytic assays, analytical grade $\mathrm{Na}_{2} \mathrm{SO}_{4}$ and $\mathrm{FeSO}_{4} \cdot 7 \mathrm{H}_{2} \mathrm{O}$ purchased from Vetec Quimica Fina were added to the drug solutions as supporting electrolyte and Fenton catalyst, respectively. Prior to acute toxicity analyses, the remaining $\mathrm{H}_{2} \mathrm{O}_{2}$ was quenched by adding catalase (10,000-50,000 units per mg of protein, Sigma-Aldrich). All the other reagents used were purchased from Vetec Quimica fina and Sigma-Aldrich, being of HPLC or analytical grade.

Several PEF trials were carried out by spiking 4-AA into a municipal secondary effluent, which was collected from a municipal WWTP located in Campo Grande, the capital of Mato Grosso do Sul state, Brazil. Physicochemical analysis of the above sample, collected in Table S2, was made after filtration with a $10 \mathrm{~mm}$ filter. Before use in the electrolytic experiments, the sample was maintained at $4{ }^{\circ} \mathrm{C}$ in a refrigerator.

A jacketed, undivided, open, cylindrical glass tank reactor of $150 \mathrm{~mL}$ capacity was employed for all the assays. In each experiment, $100 \mathrm{~mL}$ of solutions were treated under stirring at $800 \mathrm{rpm}$, keeping the temperature at $25^{\circ} \mathrm{C}$ with thermostated water. The electrolytic trials were performed with a BDD anode and a carbon-PTFE air-diffusion cathode, both of $3 \mathrm{~cm}^{2}$ geometric area and separated about $1 \mathrm{~cm}$. The BDD anode was a thin film deposited on a single-crystal p-type Si (100) wafer, which was purchased from NeoCoat (La-Chaux-de-Fonds, Switzerland). The air-diffusion cathode was supplied by E-TEK (Somerset, NJ, USA) and was mounted as described elsewhere. ${ }^{[18]}$ Compressed air at $1 \mathrm{~L} \mathrm{~min}{ }^{-1}$ was directly supplied to it for continuous $\mathrm{H}_{2} \mathrm{O}_{2}$ production. The assays were made galvanostatically and the constant current was provided by an Instrutherm Fa-3003 power source. In the PEF experiments, the solutions were illuminated with a Philips TL/4W/08 fluorescent black light blue tube $\left(\lambda_{\max }\right.$ $=360 \mathrm{~nm}$ ) placed $6 \mathrm{~cm}$ above their surface. The incident photon intensity of the lamp was of $2.92 \times 10^{19}$ photon $\mathrm{s}^{-1}$, as determined by standard potassium ferrioxalate actinometry. ${ }^{[57]}$ The surface of both electrodes was previously cleaned and activated upon polarization in $0.050 \mathrm{M} \mathrm{Na}_{2} \mathrm{SO}_{4}$ at $300 \mathrm{~mA} \mathrm{~cm}^{-2}$ for $180 \mathrm{~min}$.

The solution $\mathrm{pH}$ was monitored with a Crison $2000 \mathrm{pH}$-meter. Once the aliquots were withdrawn from the solutions, they were filtered with Phenomenex $0.45 \mu \mathrm{m}$ PTFE filters before analysis. Reversed-phase highperformance liquid chromatography (HPLC) was employed to monitor the 4-AA concentration. This analysis was carried out with a Thermo Scientific Finnigan Surveyor system, fitted with an Agilent Technologies Zorbax Eclipse XDB-C-18, $5 \mu \mathrm{m}, 250 \mathrm{~mm} \times 4.6 \mathrm{~mm}$ (i.d.) column, and coupled to a photodiode array detector set at $\lambda=274 \mathrm{~nm}$. Filtered samples were diluted $(1: 1)$ with acetonitrile $\left(7 \% \mathrm{NH}_{3}\right)$ to stop the degradation process and further, $25 \mu \mathrm{L}$ aliquots were injected into the above LC and eluted with a mobile phase composed of a (60:40) methanol/water mixture at $0.5 \mathrm{~mL}$ $\mathrm{min}^{-1}$. The chromatograms displayed the 4-AA peak at $6.5 \mathrm{~min}$ (LOD = $0.025 \mathrm{mg} \mathrm{L}^{-1}$ ). The analysis of dissolved TOC was employed to monitor the drug mineralization. It was measured on a Shimadzu TOC-V CPN analyzer by injecting $50 \mu \mathrm{L}$ aliquots after immediate withdrawal of the sample $\left(\right.$ LOD $\left.=0.053 \mathrm{mg} \mathrm{L}^{-1}\right)$. Duplicated assays were made under all degradation and mineralization conditions and the average value is given in each case. The ammonium and nitrate concentrations were obtained from the standard methods SM4500- $\mathrm{NH}_{3} \mathrm{C}$ (titrimetric method) and SM $4500-\mathrm{NO}_{3}-\mathrm{E}$, respectively. ${ }^{[58]}$

The mortality of the larvae of microcrustacean Artemia salina was employed to assess the acute toxicity in the raw municipal secondary effluent and the untreated and treated solutions with the pollutant 4-AA.
Tests were performed after hatching of the cystic in aerated synthetic seawater (32 $\left.\mathrm{g} \mathrm{L}^{-1}, \mathrm{pH} 8-9\right)$ for $48 \mathrm{~h}$. They were carried out at $20^{\circ} \mathrm{C}$ in duplicate (5 individuals per replicate) using well cell culture plates of $3 \mathrm{~mL}$, with a period involving $8 \mathrm{~h}$ dark and $16 \mathrm{~h}$ light for $96 \mathrm{~h}$. From counting the dead larvae for five dilutions $(70,50,25,12.5$ and $6.25 \% \mathrm{v} / \mathrm{v})$, LC $_{50}$ values within $96 \mathrm{~h}$ of exposure were calculated. ${ }^{[59]}$ Tests were made after removing the iron of samples at $\mathrm{pH} 8$ upon filtration with $0.45 \mu \mathrm{m}$ filters.

\section{Acknowledgements}

The authors wish to thank the Brazilian funding agencies: Conselho Nacional de Desenvolvimento Científico e Tecnológico (CNPq), Coordenação de Aperfeiçoamento de Pessoal de Nível Superior (Capes, finance code 001), and Fundação de Apoio ao Desenvolvimento do Ensino, Ciência e Tecnologia do Estado de Mato Grosso do Sul (Fundect). Thanks are extended to the Water and Sewage Utility operating in Campo Grande, Mato Grosso do Sul, for kindly providing the municipal secondary efluente sample. Funding from project CTQ2016-78616-R (AEl/FEDER, EU) is also acknowledged.

Keywords: Acute toxicity - 4-Aminoantiyrine - Municipal secondary effluent - Photoelectro-Fenton - Response surface methodology

[1] M. J. Gómez, C. Sirtori, M., Mezcua, A. R. Fernández-Alba, A. Agüera Water Res. 2008, 42, 2698-2706.

[2] L. Prieto-Rodríguez, I. Oller, N. Klamerth, A. Agüera, E. M. Rodríguez, S Malato, Water Res. 2013, 47, 1521-1528.

[3] M. C. Campos-Mañas, P. Plaza-Bolaños, J. A. Sánchez-Pérez, S. Malato A. Agüera, J. Chromatogr. A 2017, 1507, 84-94

[4] E. Brillas, I. Sirés, TrAC-Trend Anal. Chem. 2015, 70, 112-121.

[5] A. J. Ebele, M. Abou-Elwafa Abdallah, S. Harrad, Emerg. Contam. 2017, 3, 1-16.

[6] X. Hu, J. Yang, C. Yang, J. Zhang, Chem. Eng. J. 2010, 161, 68-72.

[7] J. L. Gowda, A. T. Buddanavar, S. T. Nandibewoor, J. Pharm. Anal. 2015 5, 231-238.

[8] P. M. P. Santos, A. M. M. Antunes, J. Noronha, E. Fernandes, A. J. S. C Vieira, Eur. J. Med. Chem. 2010, 45, 2258-2264.

[9] I. Muñoz, A. Rodríguez, R. Rosal, A. R. Fernández-Alba, Sci. Total Environ. 2009, 407, 1245-1256.

[10] D. Li, H. -X. Tong, L. Zhang, Trans. Nonferrous Met. Soc. China 2013, 23, 3306-3311.

[11] L. M. da Silva, F. Gozzi, I. Sirés, E. Brillas, S. C. De Oliveira, A. Machulek Jr., Sci. Total Environ. 2018, 631-632, 1079-1088.

[12] S. Gligorovski, R. Strekowski, S. Barbati, D. Vione, Chem. Rev. 2015, 115, 13051-13092.

[13] R. P. Cavalcante, R. F. Dantas, B. Bayarri, O. Gonzalez, J. Giménez, S Esplugas, A. Machulek Jr., Appl. Catal. B: Environ. 2016, 194, 111-122.

[14] L. M. da Silva, R. P. Cavalcante, R. F. Cunha, F. Gozzi, R. F. Dantas, S. C. Oliveira, A. Machulek Jr., Sci. Total Environ. 2016, 573, 518-531.

[15] R. Salazar, S. Garcia-Segura, M.S. Ureta-Zañartu, E. Brillas, Electrochim. Acta 2011, 56, 6371-6379.

[16] G. Coria, I. Sirés, E. Brillas, J. L. Nava, Chem. Eng. J. 2016, 304, 817825.

[17] N. Flores, P. L. Cabot, F. Centellas, J. A. Garrido, R. M. Rodríguez, E. Brillas, I. Sirés, J. Hazard. Mater. 2017, 321, 566-575.

[18] D. R. V. Guelfi, F. Gozzi, I. Sirés, E. Brillas, A. Machulek Jr., S. C. de Oliveira, Environ. Sci. Pollut. Res. 2017, 24, 6083-6095.

[19] I. Sirés, E. Brillas, Environ. Int. 2012, 40, 212-229. 
[20] L. Feng, E. D. Van Hullebusch, M. A. Rodrigo, G. Esposito, M. A. Oturan, Chem. Eng. J. 2013, 228, 944-964.

[21] I. Sirés, E. Brillas, M. A. Oturan, M. A. Rodrigo, M. Panizza, Environ. Sci. Pollut. Res. 2014, 21, 8336-8367.

[22] M. A. Oturan, J. -J. Aaron, Crit. Rev. Environ. Sci. Technol. 2014, 23 2577-2641.

[23] C. A. Martínez-Huitle, M. A. Rodrigo, I. Sirés, O. Scialdone, Chem. Rev. 2015, 115, 13362-13407.

[24] A. Khataee, A. Khataee, M. Fathinia, B. Vahid, S. W. Joo, J. Ind. Eng Chem. 2013, 19, 1890-1894.

[25] A. Khataee, A. Akbarpour, B. Vahid, J. Taiwan Inst. Chem. Eng. 2014, 45, 930-936.

[26] N. Daneshvar, S. Aber, V. Vatanpour, M. H. Rasoulifard, J. Electroanal. Chem. 2008, 615, 165-174.

[27] M. Panizza, M. A. Oturan, Electrochim. Acta 2011, 56, 7084-7087.

[28] M. S. Yahya, N. Oturan, K. El Kacemi, M. El Karbane, C. T. Aravindakumar, M. A. Oturan, Chemosphere 2014, 117, 447-454.

[29] F. Sopaj, M. A. Rodrigo, N. Oturan, F. I. Podvorica, J. Pinson, M. A. Oturan, Chem. Eng. J. 2015, 262, 286-294.

[30] O. Ganzenko, N. Oturan, I. Sirés, D. Huguenot, E. D. van Hullebusch, G. Esposito, M. A. Oturan, Environ. Chem. Lett. 2018, 16, 281-286.

[31] A. Thiam, I. Sirés, E. Brillas, Water Res. 2015, 81, 178-187.

[32] A. Thiam, I. Sirés, J. A. Garrido, R. M. Rodríguez, E. Brillas, Sep. Purif. Technol. 2015, 140, 43-52.

[33] X. Yu, M. Zhou, G. Ren, L. Ma, Chem. Eng. J. 2015, 263, 92-100.

[34] J. R. Steter, E. Brillas, I. Sirés, Electrochim. Acta 2016, 222, 1464-1474.

[35] J. R. Steter, E. Brillas, I. Sirés, Appl. Catal. B: Environ. 2018, 224, 410418.

[36] D. R.V. Guelfi, Z. Ye, F. Gozzi, S. C. de Oliveira, A. Machulek Jr., E. Brillas, I. Sirés, Sep. Purif. Technol. 2019, 211, 637-645.

[37] A. El-Ghenymy, R. M. Rodríguez, E. Brillas, N. Oturan, M. A. Oturan, Environ. Sci. Pollut. Res. 2014, 21, 8368-8378.

[38] A. Galia, S. Lanzalaco, M.A. Sabatino, C. Dispenza, O. Scialdone, I. Sirés, Electrochem. Commun. 2016, 62, 64-68.

[39] O. Ganzenko, N. Oturan, D. Huguenot, E. D. van Hullebusch, G. Esposito, M. A. Oturan, Separ. Purif. Technol. 2015, 156, 987-995.

[40] A. Thiam, I. Sirés, J. A. Garrido, R. M. Rodríguez, E. Brillas, J. Hazard Mater. 2015, 290, 34-42.

[41] F. Sopaj, N. Oturan, J. Pinson, F. Podvorica, M. A. Oturan, Appl. Catal. B: Environ. 2016, 199, 331-341.
[42] J. C. Murillo-Sierra, E. Ruiz-Ruiz, L. Hinojosa-Reyes, J. L. Guzmán-Mar, F. Machuca-Martínez, A. Hernández-Ramírez, Catal. Today 2018, 313 175-181.

[43] E. H. Herman, J. Zhang, B. B. Hasinoff, J. R. J. Clark, V. J. Ferrans, J. Mol. Cell Cardiol. 1997, 29, 2415-2430.

[44] M. G. A. E. Wahed, M. A. Elmesallamy, H. M. Kater, M. M. E. Gamel, N A. Khalil, Arab. J. Chem. 2011, 4, 169-178.

[45] R. P. Cavalcante, L. R. Sandim, D. Bogo, A. M. J. Barbosa, M. E. Osugi M. Blanco, S. C. de Oliveira, M. F. C. Matos, A. Machulek Jr., Environ. Sci. Pollut. Res. 2013, 20, 2352-2361.

[46] I. P. Pozdnyakov, A. A. Melnikov, R. Šípoš, S. V. Chekalin, J. Šima, Chem. Phys. Lett. 2016, 660, 209-213.

[47] M. B. Kasiri, A. R. Khata, Desalination 2011, 270, 151-159.

[48] M. A. Bezerra, R. E. Santelli, E. P. Oliveira, L. S. Villar, L. A. Escaleira, Talanta 2008, 76, 965-977.

[49] I. M. Savic, M. Savic, M. Iva, S. T. Stojiljkovic, D. G. Gajic, Energy 2014, 77, 66-72.

[50] R. F. P. Nogueira, M. C. Oliveira, W. C. Paterlini, Talanta 2005, 66, 8691.

[51] P. Calza, V. A. Sakkas, C. Medana, A. D. Vlachou, F. Dal Bello, T. A. Albanis, Appl. Catal. B: Environ. 2013, 129, 71-79.

[52] R. G. Brereton, Chemometrics. Data Analysis for the Laboratory and Chemical Plant, Wiley, Chichester, 2003.

[53] B. Singh, R. Kumar, N. Ahuja, Crit. Rev. Ther. Drug Carrier Syst. 2004 22, 27-105.

[54] M. Marković, M. Jović, D. Stanković, V. Kovačević, G. Roglić, G. GojgićCvijović, D. Manojlović, Sci. Total Environ. 2015, 505, 1148-1155.

[55] D. A. da Silva, R. P. Cavalcante, R. F. Cunha, A. Machulek Jr., S. C. de Oliveira, Chemosphere 2018, 207, 457-468.

[56] G. Persoone, B. Marsalek, I. Blinova, A. Torkokne, D. Zarina, L. Manusadzianas, G. Nalecz-Jawecki, L. Tofan, N. Stepanova, L. Tothova B. Kolar, Environ. Toxicol. 2003, 18, 395-402.

[57] A. Machulek Jr., J. E. F. Moraes, C. Vautier-Giongo, C. A. Silverio, L. C. Friedric, C. A. O. Nascimento, Environ. Sci. Technol, 2007, 41, 84598463

[58] APHA. Standard Methods for the Examination of Water and Wastewater. 22nd ed., American Public Health Association, New York, 2012.

[59] L. El Fels, M. Hafidi, Y. Ouhdouch, Waste Manage. 2016, 50, 194-200. 
Entry for the Table of Contents (Please choose one layout)

Layout 1:

\section{ARTICLE}

Text for Table of Contents

Layout 2:

\section{ARTICLE}

L.M da Silva, F. Gozzi, R.P. Cavalcante, S.C. de Oliveira, E. Brillas, I Sirés, ${ }^{\star} A$. Machulek Jr.*

Page No.1 - Page No. 11

Treatment of 4-aminoantipyrine by PEF: The application of PEF process with a BDD anode under UVA illumination is highly efficient for the degradation and mineralization of this pollutant in municipal secondary effluent and provides a decontaminated water without acute toxicity to Artemia salina.
Author(s), Corresponding Author(s)*

Page No. - Page No.

Title 
Assessment of 4-aminoantipyrine degradation and mineralization by photoelectro-Fenton with a BDD anode: Optimization, treatment in municipal secondary effluent, and toxicity

Lucas de Melo da Silva, ${ }^{[a]}$ Fábio Gozzi, ${ }^{[a]}$ Rodrigo Pereira Cavalcante, ${ }^{[a]}$ Silvio César de Oliveira, ${ }^{[a]}$ Enric Brillas, ${ }^{[b]}$ Ignasi Sirés, ${ }^{*[b]}$ and Amílcar Machulek Junior*[a]

[a] Mr. L.M da Silva, Dr. F. Gozzi, Dr. R.P. Cavalcante, Prof. S.C. de Oliveira, Prof. A. Machulek Jr. Institute of Chemistry,

Federal University of Mato Grosso do Sul

Av. Senador Filinto Muller, 1555; CP 549; Campo Grande, MS 79074-460, Brazil

E-mail: machulekjr@gmail.com

[b] Prof. E. Brillas, Prof. I Sirés

Departament de Química Física

Facultat de Química, Universitat de Barcelona

Martí i Franquès 1-11, 08028 Barcelona, Spain

E-mail: i.sires@ub.edu 
Table S1. Experimental parameters corresponding to the trials given in Table 2.

\begin{tabular}{|c|c|c|c|c|c|}
\hline Trial & $\begin{array}{l}\text { Current density } \\
\left.\qquad(\mathrm{mA} \mathrm{cm})^{-2}\right)\end{array}$ & $\begin{array}{c}{\left[\mathrm{Fe}^{2+}\right]} \\
\left(\mathrm{mg} \mathrm{L}^{-1}\right)\end{array}$ & $\begin{array}{l}{[4-\mathrm{AA}]} \\
\left(\mathrm{mg} \mathrm{L}^{-1}\right)\end{array}$ & $\begin{array}{l}\text { Time for \% 4-AA } \\
\text { degradation } \\
\text { (min) }\end{array}$ & $\begin{array}{l}\text { Time for \% 4-AA } \\
\text { mineralization } \\
\text { and } \% \text { MCE (min) }\end{array}$ \\
\hline 1 & 32.5 & 17.25 & 62.5 & 3 & 50 \\
\hline 2 & 32.5 & 17.25 & 62.5 & 7 & 130 \\
\hline 3 & 32.5 & 17.25 & 137.5 & 3 & 50 \\
\hline 4 & 32.5 & 17.25 & 137.5 & 7 & 130 \\
\hline 5 & 32.5 & 47.75 & 62.5 & 3 & 50 \\
\hline 6 & 32.5 & 47.75 & 62.5 & 7 & 130 \\
\hline 7 & 32.5 & 47.75 & 137.5 & 3 & 50 \\
\hline 8 & 32.5 & 47.75 & 137.5 & 7 & 130 \\
\hline 9 & 77.5 & 17.25 & 62.5 & 3 & 50 \\
\hline 10 & 77.5 & 17.25 & 62.5 & 7 & 130 \\
\hline 11 & 77.5 & 17.25 & 137.5 & 3 & 50 \\
\hline 12 & 77.5 & 17.25 & 137.5 & 7 & 130 \\
\hline 13 & 77.5 & 47.75 & 62.5 & 3 & 50 \\
\hline 14 & 77.5 & 47.75 & 62.5 & 7 & 130 \\
\hline 15 & 77.5 & 47.75 & 137.5 & 3 & 50 \\
\hline 16 & 77.5 & 47.75 & 137.5 & 7 & 130 \\
\hline 17 & 10.0 & 32.5 & 100.0 & 5 & 90 \\
\hline 18 & 100.0 & 32.5 & 100.0 & 5 & 90 \\
\hline 19 & 55.0 & 2.0 & 100.0 & 5 & 90 \\
\hline 20 & 55.0 & 63.0 & 100.0 & 5 & 90 \\
\hline 21 & 55.0 & 32.5 & 25.0 & 5 & 90 \\
\hline 22 & 55.0 & 32.5 & 175.0 & 5 & 90 \\
\hline 23 & 55.0 & 32.5 & 100.0 & 1 & 10 \\
\hline 24 & 55.0 & 32.5 & 100.0 & 9 & 170 \\
\hline 25 & 55.0 & 32.5 & 100.0 & 5 & 90 \\
\hline 26 & 55.0 & 32.5 & 100.0 & 5 & 90 \\
\hline 27 & 55.0 & 32.5 & 100.0 & 5 & 90 \\
\hline
\end{tabular}


Table S2. Physicochemical characteristics of the municipal secondary effluent sample.

\begin{tabular}{|c|c|}
\hline Parameter ${ }^{[a]}$ & Value \\
\hline $\mathrm{pH}$ & 7.06 \\
\hline Conductivity $\left(\mathrm{mS} \mathrm{cm}^{-1}\right)$ & 2.4 \\
\hline Alkalinity (mg L-1) & 70 \\
\hline $\mathrm{BOD}\left(\mathrm{mg} \mathrm{L}^{-1}\right)$ & 10.8 \\
\hline $\operatorname{COD}\left(\mathrm{mg} \mathrm{L}^{-1}\right)$ & 40.1 \\
\hline TOC $\left(\mathrm{mg} \mathrm{L}^{-1}\right)$ & 10.5 \\
\hline Phosphorus (mg L-1) & 1.72 \\
\hline Ammonia nitrogen $\left(\mathrm{mg} \mathrm{L}^{-1}\right)$ & 1.4 \\
\hline Kjeldahl nitrogen (mg L ${ }^{-1}$ ) & 4.4 \\
\hline Chloride $\left(\mathrm{mg} \mathrm{L}^{-1}\right)$ & 35.6 \\
\hline Nitrite $\left(\mathrm{mg} \mathrm{L}^{-1}\right)$ & 0.7 \\
\hline Nitrate $\left(\mathrm{mg} \mathrm{L}^{-1}\right)$ & 1.4 \\
\hline Oils and greases $\left(\mathrm{mg} \mathrm{L}^{-1}\right)$ & 5.8 \\
\hline Suspended Solids $\left(\mathrm{mg} \mathrm{L}^{-1}\right)$ & 16 \\
\hline Total solids (mg L $\left.{ }^{-1}\right)$ & 263 \\
\hline Dissolved Solids $\left(\mathrm{mg} \mathrm{L}^{-1}\right)$ & 247 \\
\hline
\end{tabular}

[a] Data provided by the Water and Sewage Utility operating in Campo Grande, Mato Grosso do Sul, Brazil. 
a
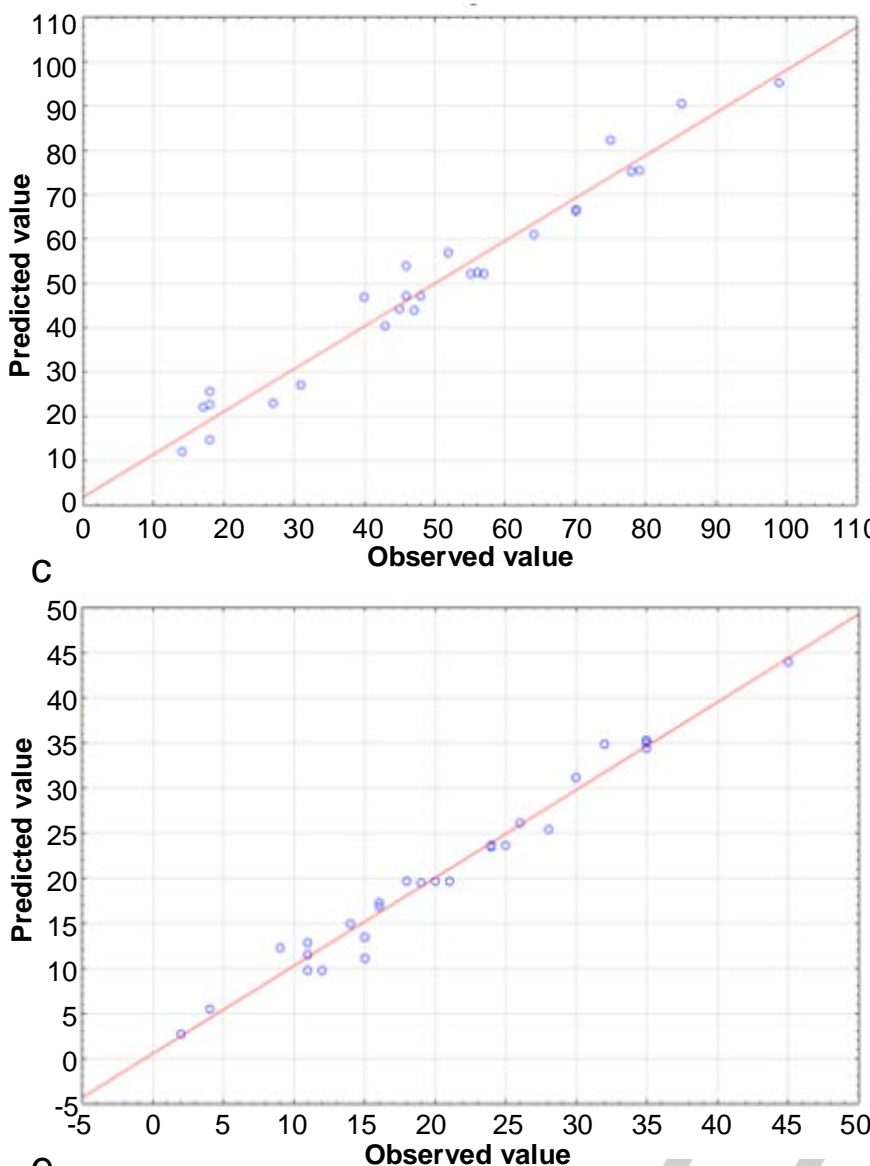

e

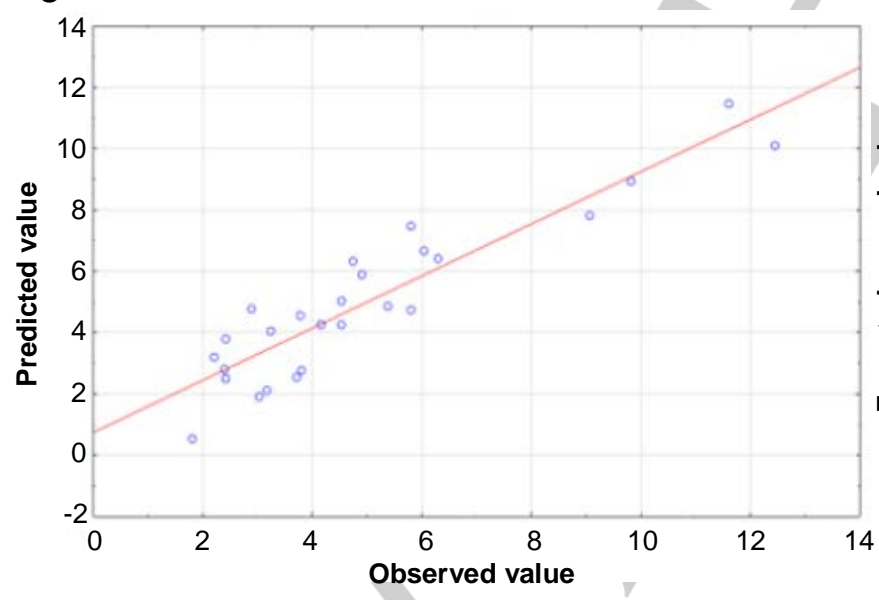

b
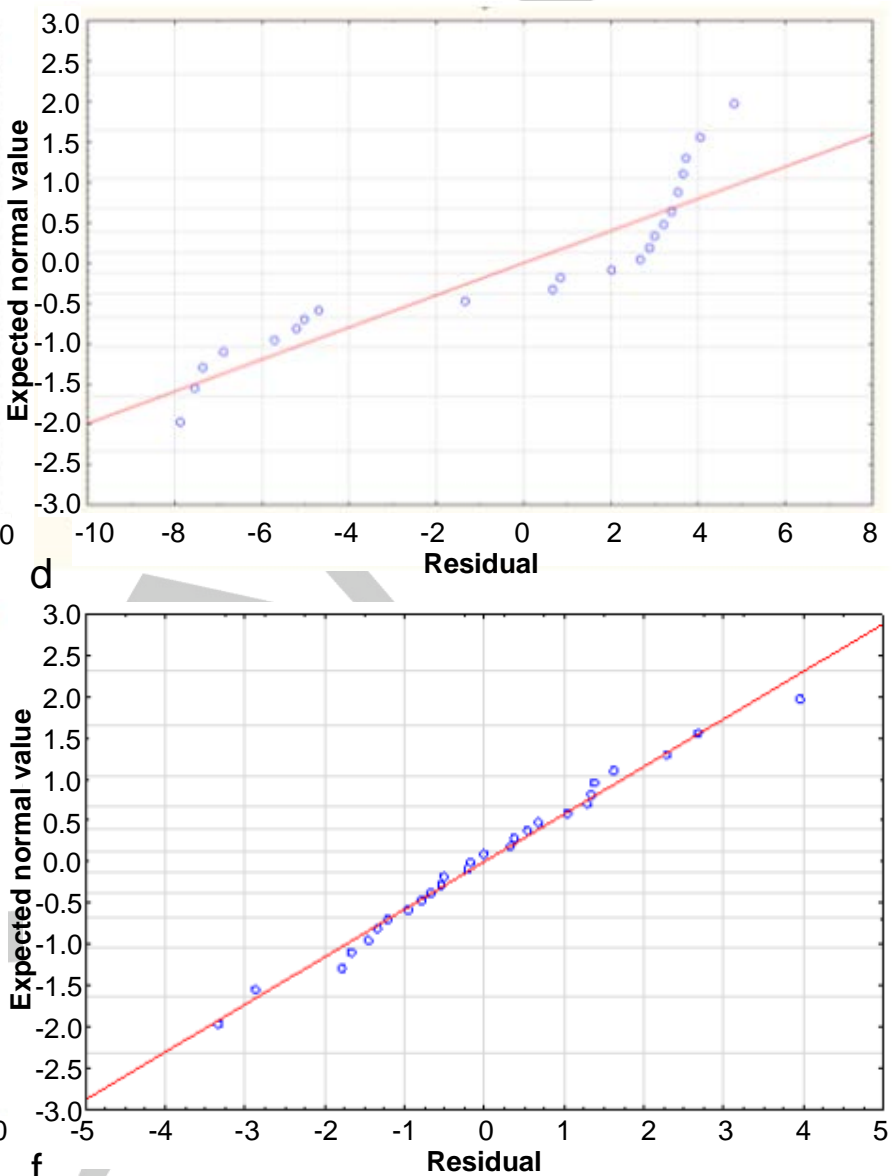

$f$

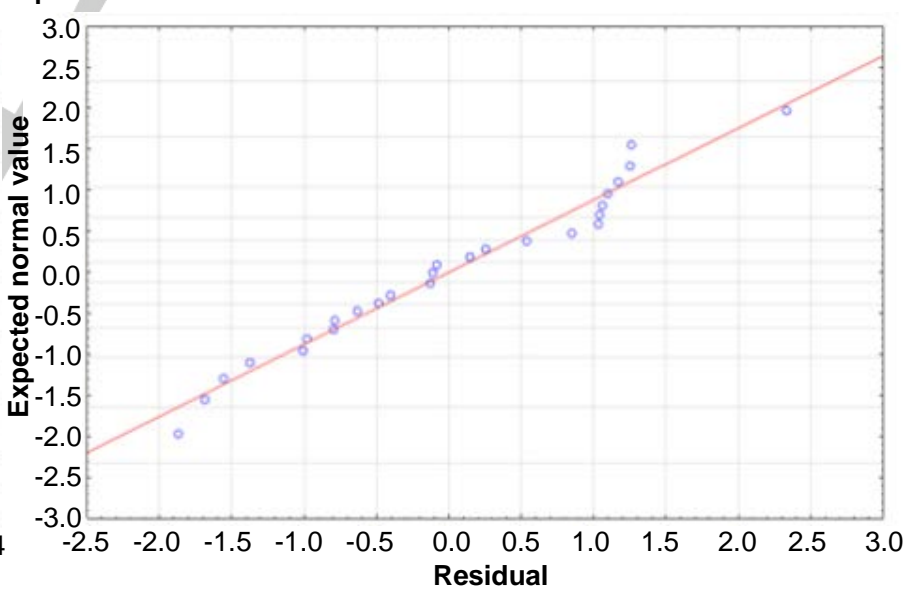

Figure S1. Comparison of predicted and observed values for the percentage of: (a) 4-AA degradation, (c) 4-AA mineralization, and (e) mineralization current efficiency. Residual plots for the responses of the percentages of: (b) 4-AA degradation, (d) 4-AA mineralization, and (e) mineralization current efficiency. 